\title{
A Evolução do IASC para o IASB e os Desafios Enfrentados
}

Stephen A. Zeff

Rice University

Publicado no The Accounting Review em janeiro de 2012

\section{RESUMO}

Este artigo apresenta uma revisão dos principais desenvolvimentos e marcos na evolução do International Accounting Standards Committee (IASC), seguida pela evolução do International Accounting Standards Board (IASB). Na conclusão, são sugeridos cinco desafios enfrentados pelo IASB.

Palavras-chave: IASC. IASB. IAS. IFRS. Normalização. Regulamentação.

Nota do Editor: Este comentário, elaborado com base em uma palestra proferida na Reunião Anual da American Accounting Association de 2011 em Denver, Colorado, EUA, foi submetido a convite do Editor Sênior Johan Harry Evans III, em conformidade com a meta do Comitê Executivo da AAA de promover a ampla disseminação da Palestra do Presidential Scholar da AAA. 
Nos últimos anos, a maioria dos estudiosos na área da contabilidade tem acompanhado de perto o International Accounting Standards Board (IASB) e a produção de suas Normas Internacionais de Relatórios Financeiros (IFRS). Em sua curta existência, desde 2001, o IASB redesenhou substancialmente o mapa mundial das informações financeiras empresariais. Entretanto, foi o International Accounting Standards Committee (IASC), durante seus 27 anos, de 1973 a 2000, que serviu de palco para o IASB, que, por sua vez, nasceu do IASC ${ }^{1}$. Mostra-se oportuno esboçar uma perspectiva histórica que possa lançar luz sobre o IASB de hoje. Neste artigo serão enfocados os principais desenvolvimentos e marcos nesses 37 anos da sua evolução, sugerindo alguns dos desafios que o IASB enfrenta hoje.

A história contada neste artigo baseia-se em pesquisas históricas. Tal investigação raramente produz explicações simples e claras das causas e efeitos e dos motivos para eventos e desenvolvimentos. Apesar disso, procurei utilizar os frutos desta pesquisa para explicar a evolução em forma de história, porém, com apartes e eventuais qualificações e digressões para revelar mais que duas dimensões. Darei maior destaque aos primeiros que aos últimos anos, não somente porque é mais difícil obter uma perspectiva histórica de eventos e desenvolvimentos muitos recentes, mas, também, porque o IASB recebeu muito mais atenção de um público mais amplo nos últimos anos.
A evolução do IASC e IASB é a história de um órgão de normalização contábil internacional do setor privado que conseguiu ganhar respeito e apoio, inicialmente das entidades contábeis nacionais, seguidas pelos órgãos de normalização nacionais e, finalmente, pelos reguladores dos principais mercados de capitais e dos ministérios governamentais, além dos preparadores e usuários de demonstrações contábeis ao redor do mundo. Parte de seu sucesso deve-se ao timing: era o único órgão competente de normalização contábil internacional no final dos anos 1990, quando a União Europeia (UE) se debruçava sobre a criação do mercado de capitais interno e a Comissão Europeia estava em busca de uma alternativa aos Princípios Contábeis Geralmente Aceitos dos EUA (US GAAP) como fonte de normas contábeis exigidas para as empresas negociadas em bolsa naquele mercado. A proposta-surpresa da Comissão Europeia, emitida em 2000 para engajar as empresas negociadas em bolsa da UE na adoção das Normas Contábeis Internacionais até 2005, chamou a atenção mundial e outros países começaram a considerar seriamente o IASC como órgão global de normalização contábil. Com essa aceitação de suas normas, o IASB (como o IASC passou a ser conhecido a partir de 2001) iniciou um jogo de elevadas apostas no qual as empresas e os governos participaram como players proativos e os reguladores ocuparam um lugar na mesa.

\section{CONTEXTO DE FUNDAÇÃO DO IASC}

Após a Segunda Guerra Mundial, cada país tinha seus próprios Princípios Contábeis Geralmente Aceitos (GAAP, terminologia norte-americana), ou sua própria prática contábil. Inclusive entre os GAAP em países com mercados de capitais ativos, dos quais as companhias negociadas em bolsa dependiam fortemente para captação de recursos - os EUA, o Canadá, o Reino Unido, a Austrália e a Nova Zelândia -, havia importantes diferenças. Por exemplo, no Reino Unido, na Austrália e na Nova Zelândia, era permitido às empresas reavaliar seus ativos fixos tangíveis, inclusive suas propriedades para investimento. Nos EUA e no Canadá, principalmente por causa da influência conservadora da Comissão de Valores Mobiliários (SEC) (ver Zeff, 2007a), as companhias aderiram ao custo histórico. $\mathrm{Na}$ América do Norte, o Último que Entra, Primeiro que Sai (UEPS) estava amplamente disponível para fins de estoque nos EUA, porém, no Canadá ele limitava-se a poucas indústrias (Skinner, 1972, pp. 79). Em 1975, o órgão normalizador neozelandês emitiu uma norma, a SSAP 3, sobre depreciação, que exigiu o uso do método linear (ver Zeff, 1979, pp. 59). Nenhum outro país fez o mesmo.

Uma distância ainda maior existia entre os GAAP nesses países anglo-americanos e aqueles em países do conti- nente europeu e no Japão, onde o imposto de renda dirigia as práticas contábeis, onde o lucro declarado determinava por lei o dividendo a ser declarado e onde os resultados contábeis eram passíveis de manipulação por meio de reservas secretas. Em 1947, a França estabeleceu o Plan Comptable General (Plano Contábil Nacional), um regulamento detalhado, codificado da contabilidade empresarial, posteriormente exportado para Bélgica e Espanha e, por fim, para Portugal, Marrocos, Tunísia, Argélia e Peru (ver Scheid \& Walton, 1992, cap. 7). Na maioria dos países em desenvolvimento, a divulgação contábil era mínima e havia pouco a ser denominado GAAP além da possível herança dos antigos colonizadores, tais como o Reino Unido e a França. Em suma, a prática contábil global era bastante diversificada (ver, por exemplo, Nobes, 1983) e a comparação significativa entre as demonstrações contábeis de diferentes países era muito difícil.

Os anos 1950 iniciaram o período de crescimento rápido no comércio internacional e no investimento direto estrangeiro e as empresas começaram a ampliar seu alcance para além de suas fronteiras. As lideranças da profissão contábil consideravam "internacional” o novo desafio. O American Institute of Certified Public Accountants (AI-

A maioria dos fatos apresentados neste artigo que fundamentam a discussão do período do IASC, de 1973 a 2000, foram obtidos de Camfferman e Zeff (2007). Naqueles momentos em que o leitor deseje consultar a discussão mais ampla do livro, com eventuais citações relevantes, indicarei (CZ 2007) e os números da página ou capítulo. 0 capítulo 1 do livro apresenta uma visão geral de 12 páginas sobre a evolução do IASC. 
CPA) realizou o $8^{\circ}$ Congresso Internacional de Contadores em Nova York, em setembro de 1962, com o tema contabilidade e auditoria na economia global. Menos de dois anos depois foi publicado Professional accounting in 25 countries (American Institute of Certified Public Accountants, 1964), o primeiro grande levantamento das normas de contabilidade, auditoria e da profissão ao redor do mundo (CZ 2007, pp. 21-26).

Os anos 1960 foram marcados por fusões e aquisições internacionais frequentes, particularmente empresas americanas assumindo companhias europeias e empresas inicialmente domésticas que começaram a redistribuir suas operações produtivas e sua equipe gerencial em nível internacional. Em abril de 1963, a revista Business Week publicou um relatório especial sobre a nova forma de organização empresarial, denominada "empresas multinacionais". "Multinacional", segundo a revista, "serve como linha de demarcação entre empresas com orientação doméstica com operações internacionais e companhias com orientação verdadeiramente global" (Multinational Companies, 1963, pp. 63). Essa tendência internacionalista aguçou o desejo de comparar as demonstrações contábeis elaboradas em diferentes países.

Sir Henry Benson (posteriormente Lord Benson), sócio sênior na empresa britânica Cooper Brothers \& Co. (pos- teriormente Coopers \& Lybrand e hoje parte da PricewaterhouseCoopers) e presidente do Institute of Chartered Accountants in England and Wales (ICAEW) em 1966-67, liderou um movimento para abordar a questão das diversas práticas contábeis. Benson, nascido e criado na África do Sul, que posteriormente emigrou para o Reino Unido, era um homem determinado e engenhoso. Em 1966, convenceu o AICPA, o Canadian Institute of Chartered Accountants (CICA), o Institute of Chartered Accountants of Scotland e o Institute of Chartered Accountants in Ireland a se juntar ao ICAEW para constituir o Accountants International Study Group (AISG). O AISG lançou uma série de livretos que comparou as abordagens contábeis e de auditoria nos EUA, no Canadá e no Reino Unido. Entre outros fatores, Benson esperava que uma comparação das abordagens de auditoria nos três países finalmente convenceria a profissão contábil britânica a exigir a presença do auditor na elaboração dos inventários, e ele teve sucesso nesse empreendimento. Ao longo de um período de mais de 10 anos, o AISG lançou 20 desses livretos, que representaram o primeiro grande esforço para comparar e contrastar as práticas contábeis e de auditoria entre os principais países (CZ 2007, pp. 26-36). Os livretos do AISG destacaram a diversidade nas práticas entre os três países e, portanto, a não comparabilidade das demonstrações contábeis além das fronteiras.

\section{O LANÇAMENTO DO IASC}

A segunda iniciativa do Benson era ainda mais portentosa. Após correspondências e reuniões com as lideranças dos órgãos globais de todo o mundo, Benson liderou a fundação do International Accounting Standards Commitee (IASC). Sua motivação era promover a harmonização internacional das normas contábeis, para diminuir as diferenças nas práticas contábeis entre os países. Possivelmente, também houve motivos centrados no Reino Unido. Em 1973, o Reino Unido, junto com a Irlanda e a Dinamarca, tornaram-se membros da Comunidade Econômica Europeia (EEC, hoje conhecida como União Europeia). Até aquele momento, a abordagem alemã com orientação fiscal havia guiado o desenvolvimento da Quarta Diretriz da Lei Societária sobre a contabilidade ${ }^{2}$, que deveria ser incorporada à legislação de todos os Estados membros após sua aprovação pelo conselho dos ministros. Benson e outros indivíduos no Reino Unido podem ter acreditado que o IASC seria capaz de promover normas mais alinhadas à abordagem anglo-americana de contabilidade e, portanto, serviriam de contrapeso à tendência do desenvolvimento contábil da EEC. Anthony Hopwood (1994, pp. 243) discutiu que "um impulso fundamental para o estabelecimento do IASC" foi a prevenção "da imposição [na EEC] do controle estatutário e público da Europa continental sobre o relacionamento muito mais discricionário entre a gestão corporativa e o auditor no Reino Unido".

A noção da "imagem verdadeira e fiel" na lei societária britânica era algo exclusivo da cultura contábil daquele país e não havia contrapartida na legislação continental. Benson também pode ter feito pressão a favor do IASC porque não o agradava a qualidade das normas contábeis britânicas e porque acreditava, como no caso do impacto nas práticas de auditoria britânicas produzido pelo livreto do AISG sobre os estoques, que as normas e práticas contábeis britânicas poderiam beneficiar-se da participação de seus órgãos contábeis em um empreendimento global colaborativo de normalização. De fato, mesmo antes do IASC lançar sua primeira norma, Benson convenceu a Bolsa de Londres a exigir que as empresas negociadas em bolsa evidenciassem divergências das normas do IASC, pressionando, assim, o recém-lançado Accounting Standards Steering Committee britânico e as empresas daquele país a cumprir as práticas recomendadas nas normas do IASC (CZ 2007, pp. 154).

O IASC foi a primeira tentativa de normalização contábil internacional. Em 1973, poucos países tinham comitês ou conselhos cujas recomendações influenciavam o curso da prática contábil ${ }^{3}$. Em ordem cronológica, esses países foram: EUA, Reino Unido, Canadá, França, Japão, Austrália

Em 1978 e 1983, a Comissão Europeia emitiu duas Diretrizes da Lei Societária sobre contabilidade, denominadas Quarta Diretriz sobre as contas anuais e Sétima Diretriz sobre as contas consolidadas, respectivamente. Seu objetivo foi harmonizar as leis societárias dos Estados membros da EEC, que posteriormente foram obrigados a incorporá-las em suas legislações nacionais.

O termo "normalização" entrou no vocabulário contábil ativo em 1972, com o relatório do Study Group on Establishment of Accounting Principles - The Wheat Study Group (American Institute of Certified Public Accountants, 1972) nos EUA, sob o título Establishing financial accounting standards. Esse grupo de estudos recomendou a constituição do Financial Accounting Standards Board, que iniciou suas atividades em $1^{\circ}$ de julho de 1973. Para garantir, o ICAEW, junto com outros órgãos, havia lançado o Accounting Standards Steering Committee em 1969/1970, mas esse uso preliminar das "normas" não parece ter influenciado o pensamento do Wheat Study Group (carta de David Solomons, membro-chave do Wheat Study Group, ao autor, datada de 12 de fevereiro de 1981). 
e Nova Zelândia. Os Países Baixos e África do Sul haviam lançado esses órgãos apenas recentemente. Os nove países cujos órgãos contábeis nacionais foram convidados por Benson a se tornar membros do IASC foram, em ordem alfabética: Alemanha, Austrália, Canadá, EUA, França, Japão, México, Países Baixos e Reino Unido e Irlanda (combinados). Cada país era representado por uma delegação de, no máximo, 3 membros: 2 que decidiam sobre o voto da delegação e 1 observador oficial. Cada delegação tinha 1 voto. Inicialmente, somente o AICPA apoiava a delegação dos EUA mas, por fim, o Financial Executives Institute (FEI) e o Institute of Management Accountants tornaram-se coapoiadores. É uma coincidência interessante que o IASC tenha sido fundado em 29 de junho de 1973, 2 dias antes do Financial Accounting Standards Board (FASB), um órgão independente, suceder o Accounting Principles Board, que era um comitê do AICPA. O AICPA era 1 dos 5 apoiadores do Financial Accounting Foundation, que supervisionava o FASB, porém, então, também havia tornado-se o apoiador da delegação dos EUA no IASC, considerado por alguns concorrente do FASB, como descrito adiante.

Inicialmente, os membros das 9 delegações eram sócios das empresas de auditoria, profissionais de auditoria independentes, executivos de órgãos contábeis nacionais, um acadêmico e um executivo financeiro, todos trabalhando em tempo parcial. Nos anos seguintes, mais executivos financeiros e usuários das demonstrações contábeis tornaram-se membros. Além de seus "empregos fixos", os delegados participavam das reuniões do conselho do IASC 3 ou 4 vezes por ano e leram a documentação preparada pela equipe técnica de 2 funcionários de tempo integral, que trabalhavam com comitês voluntários para esboçar as normas. Pequenos comitês presididos por um membro do conselho e constituídos por voluntários de todo o mundo preparavam as versões iniciais. O objetivo do IASC era emitir normas "básicas", denominadas International Accounting Standards (IAS) que, esperava-se, pudessem levar a uma harmonização das normas contábeis ao redor do mundo. O conselho elegeu Henry Benson como presidente em sua primeira reunião.

Os órgãos contábeis nacionais firmaram o IASC Agreement and Constitution, afirmando que empregariam seus "melhores esforços" para promover o uso das normas do IASC em seus países (CZ 2007, pp. 52-53 e 500-503). Uma maioria de $3 / 4$ era exigida para aprovar projetos e normas finais. Como os membros de uma série de países defendiam a exatidão das práticas contábeis utilizadas em seus próprios países e, também, porque as delegações de alguns países preferiam a flexibilidade de ter à disposição tratamentos ou métodos contábeis opcionais, havia muitas normas emitidas com escolhas livres ${ }^{4}$. $\mathrm{O}$ voto para cada projeto e norma não era informado e nenhuma visão contrária era publicada. A equipe técnica frequentemente consultava as normas norte-americanas e britânicas, entre outras, nos esboços iniciais.

Os empregadores dos membros custearam algumas despesas de viagem, porém, os órgãos contábeis nacionais apoiadores responsabilizaram-se pela maior parte dos encargos financeiros. O aluguel e despesas relacionadas da sede em Londres eram pagos pelo ICAEW. Dentro de um ano, os órgãos contábeis de outros países começaram a se tornar membros associados, firmando o compromisso de também empregar seus "melhores esforços" para promover a aceitação das normas do conselho em seus países e concordando, ainda, em contribuir com as despesas do IASC (CZ 2007, pp. 43-67).

As reuniões do conselho representavam, provavelmente, um desafio para algumas delegações. Como as deliberações ocorriam em inglês (com vários sotaques nacionais), os membros da França, Alemanha, Japão e dos Países Baixos eram obrigados a discutir questões técnicas de contabilidade em outro idioma. Com mais de 25 membros do conselho, além da equipe, sentados ao redor de uma grande mesa, a compreensão e comunicação das perspectivas não deve ter sido fácil para todos os participantes.

Desde o início, a Comissão Europeia, ala administrativa da EEC, deu pouca atenção ao IASC. Talvez acreditasse que um órgão do setor privado atenderia apenas aos interesses de seus próprios membros, não ao interesse público que uma agência pública como a comissão almejava servir. $\mathrm{O}$ FASB, por sua vez, também deu pouca atenção ao IASC e, em vez deste último, enfocava as melhorias dos US GAAP. Como veremos, essas posturas mudaram até o final dos anos 1980.

\section{APOIO SURPRESA DA SEC EM 1975}

A SEC vinha acompanhando os desenvolvimentos internacionais da contabilidade com grande interesse e foi estimulada pelo trabalho do AISG. Em maio de 1972, o presidente da SEC, William J. Casey (1972), disse: “Talvez [o AISG] represente um início na formidável tarefa de alcançar algum nível aceitável de uniformidade contábil em uma base internacional". Um mês depois, Casey indicou John C. (Sandy) Burton como contador-chefe da SEC. Em setembro de 1973, poucos meses após o IASC iniciar suas operações, o presidente da SEC, Ray Garrett Jr. (1973), afirmou que Burton estava trabalhando com a AICPA “e vários grupos contábeis internacionais para resolver as diferenças importantes na divulgação contábil ao redor do mundo”.

Em seguida, a SEC concedeu ao novato IASC um inesperado voto de apoio. As primeiras três normas do IASC trataram da divulgação das políticas contábeis, estoques e demonstrações contábeis consolidadas. Em dezembro de 1974, o IASC emitiu o E3, projeto de uma norma sobre as demonstrações 
contábeis consolidadas, implicando que as demonstrações contábeis de subsidiárias diferentes, tais como as subsidiárias financeiras ou seguradoras de companhias-mães industriais, deveriam ser incluídas nas demonstrações contábeis consolidadas. Essa proposta contrariou os US GAAP, que excluíam tais subsidiárias da consolidação, com base no Accounting Research Bulletin n. 51, publicado em 1959. Sandy Burton preferiu a abordagem do IASC e, em 10 de junho, escreveu para a AICPA, apoiadora do IASC nos EUA, em nome da comissão:

Os princípios apresentados [no E3] não são consistentes com os princípios contábeis geralmente aceitos neste país e realmente refletem o que acreditamos ser a prática contábil preferencial. [...] Se o Comitê Internacional de Normas Contábeis emitir uma declaração final que incorpore esses princípios e se não houver nenhuma declaração oposta pelo Conselho das Normas Contábeis Financeiras, a Comissão proporá para comentários emendas ao seu Regulamento S-X, que conformará suas regras de consolidação com aquelas apresentadas na declaração.

Naquele momento, o FASB não tinha nenhum ponto em sua agenda para tratar das demonstrações contábeis consolidadas.

Ao tomar conhecimento da carta de Burton, Marshall S. Armstrong, presidente do FASB, reclamou com o presidente da SEC, Garrett Jr., expressando sua "grande preocupação com as consequências da ação proposta naquela carta. [...] Se realizada, a ação proposta poderia prejudicar gravemente a eficácia do conselho como fator significativo na melhoria das demonstrações contábeis". Na verdade, no Accounting Series Release n. 150 (Securities and Exchange Commission, 1973), publicada em dezembro, a SEC havia declarado que considerava a liderança do FASB na normalização contábil. O Presidente do FEI, Charles C. Hornbostel, protestou de forma semelhante, argumentando que a carta de Burton "não consegue compreender o fato que o IASC é um órgão não autorizado, com pouca aceitação geral pelo seu eleitorado". Henry Benson tomou conhecimento da carta do FEI e es- creveu para Garrett, com cópias para Armstrong e Hornbostel, que o Acordo e a Constituição do IASC foram "firmados por e em nome de dezesseis dos principais órgãos contábeis profissionais do mundo". Garrett respondeu: "Acreditamos que tenha trabalho suficiente para todos e que os esforços de ambos os órgãos [IASC e FASB] possam ser combinados em benefício dos mercados de capitais globais em geral e dos acionistas norte-americanos em particular, sem colocar em risco a autoridade de qualquer um dos órgãos". De fato, isso significou que a SEC não via o FASB como o único órgão a considerar para a liderança na normalização contábil. A SEC havia deixado claro que apoiava o movimento em direção às Normas Contábeis Internacionais e considerava o progresso do IASC com olhos positivos.

No final, o IASC modificou sua norma final em junho de 1976, para permitir a exclusão das subsidiárias diferentes da consolidação, e a tensão entre o FASB e a SEC prontamente se dissipou (CZ 2007, pp. 157-160). Um motivo indicado para a modificação é revelador. Joseph P. Cummings, vice-sócio sênior de Peat, Marwick, Mitchell \& Co. e membro da delegação norte-americana no IASC, havia presidido o comitê orientador para o E3. Apesar da sua crença fervorosa de que não havia lógica na exclusão das subsidiárias diferentes, após o IASC ter ouvido as objeções norte-americanas e britânicas ao E3 por contrariar os GAAP nos seus países, disse, "aprendemos uma lição". O IASC, ele disse, "sairá do papel, alcançaremos algo, desde que mantenhamos as normas relativamente básicas e desde que não ultrapassem as políticas e os princípios estabelecidos nos mercados mais sofisticados ao redor do mundo" (Cummings, 1976, pp. 5-6). Cummings (1976, p. 6), que sucedeu Benson como Presidente do IASC em julho de 1976, adicionou profeticamente:

Não sei o que faremos se realmente tivermos uma diferença violenta entre o Reino Unido e os EUA e alguns dos outros países do mercado comum em relação a algum tema. Alguém vai sofrer mais, e esse dia chegará, não há nenhuma dúvida em relação a isso. Quando chegar, teremos o verdadeiro teste de sobrevivência.

\section{REGISTRO E IMPACTO DO IASC ENTRE 1973 E 1987}

A primeira norma do IASC sobre a divulgação das políticas contábeis foi divulgada em janeiro de 1975 e foi recebida com grande alarde ao redor do mundo. Entre 1975 e 1987, o IASC publicou mais 25 normas, incluindo uma sobre refletir os efeitos das alterações de preços, que substituiu uma norma anterior (CZ 2007, cap. 5). O impacto aparente das normas do IASC variou consideravelmente entre os países. Com poucas exceções, os países representados no conselho não modificaram suas próprias normas para refletir os conteúdos das normas do IASC. Havia dois motivos para esse comportamento. Os países anglo-americanos representados no conselho geralmente consideravam suas normas superiores às IAS. A maioria dos outros países com delegações no conselho podem muito bem ter acreditado que o IASC não combinava com o modelo contábil em bases fiscais que estavam utilizando.
O comitê normalizador do CICA, que foi o órgão apoiador mais entusiasta durante os 27 anos do conselho, realmente consultou algumas normas do IASC, particularmente a IAS 18, sobre o reconhecimento de receitas, na revisão de suas próprias normas. Nos Países Baixos, o Nederlands Instituut van Registeraccountants propôs um processo que permitiu "aceitar" algumas IAS para uso obrigatório mas, no final das contas, nenhuma dessas IAS chegou a ser aceita (CZ 2007, pp. 165-166 e 172-174).

"Melhores esforços" foi interpretado de forma diferente em diferentes países, e as delegações da maioria dos países não incluíram um representante do normalizador nacional, mesmo se houvesse um no país. $\mathrm{O}(\mathrm{s})$ órgão(s) contábil(eis) apoiador(es) poderia(m) ter tido apenas uma influência limitada, se tivessem, nas práticas contábeis do seu país. 
Nos anos 1980, uma série de grandes empresas demonstrou solidariedade com o IASC. Três multinacionais norte-americanas - General Electric, Exxon e FMC Corporation - afirmaram em seus relatórios que suas demonstrações contábeis eram, na maioria dos sentidos, consistentes com as Normas Contábeis Internacionais. No Canadá, a mando da Bolsa de Toronto, após estímulo do CICA, aproximadamente 100 empresas negociadas em bolsa confirmaram em seus relatórios anuais a consistência de suas demonstrações contábeis com as normas do IASC. Naquele momento, as IAS eram compatíveis em quase todos os aspectos com os GAAP norte-americanos e canadenses. Assim, afirmar seu cumprimento não trazia quase nenhum custo para uma empresa. Em 1985, no Japão, Sasebo Heavy Industries Co., um grande estaleiro e empresa de engenharia naval, afirmou em seu relatório voluntário em língua inglesa que suas demonstrações consolidadas estavam de acordo com as IAS. De fato, em 1979, a Bolsa de Tóquio havia declarado que, a partir daquele momento, permitiria às empresas estrangeiras preparar suas demonstrações contábeis com as IAS ao invés dos GAAP japoneses. A South African Breweries confirmou, desde 1984, que suas principais políticas contábeis "estão em conformidade em todos os aspectos materiais" com as IAS (CZ 2007, cap. 6).

A quantidade de delegações no conselho aumentou gradualmente para 14, com a inclusão da África do Sul, da Nigéria, da Itália, de Taiwan, além de uma delegação de analistas financeiros. Alguns, como a África do Sul e os analistas financeiros, tornaram-se delegações permanentes e continuaram no conselho até 2000. Em 1995, a África do Sul passou a incluir um representante do Zimbabwe em sua delegação para promover a associação de países em desenvolvimento. Além da África do Sul e dos analistas financeiros, os outros (Nigéria, Itália e Taiwan) eram delegações ro- tativas com mandatos pré-definidos no conselho (CZ 2007, pp. 71-73 e 506-512). Até 1987, havia mais de 40 membros de delegações e equipe técnica sentados ao redor de uma mesa ainda maior, uma série dos quais continuavam sofrendo com o idioma inglês 5 .

De tempos em tempos o IASC enfrentava desafios de outros órgãos. Nos anos 1970 e 1980, as Nações Unidas e a Organização de Cooperação e Desenvolvimento Econômico, que haviam começado a se interessar pelas informações financeiras de empresas multinacionais, questionaram a primazia do IASC na normalização contábil internacional. Expressaram-se posições em ambos os órgãos de que faltava legitimidade ao IASC por ser uma criação da profissão contábil, com seus próprios autointeresses restritos. A International Federation of Accountants (IFAC), fundada em 1977, tentou em dois momentos, nos anos 1980 tomar sob suas asas o IASC por meio de uma fusão, mas o IASC foi bem-sucedido em impedir ambas essas tentativas para prosseguir independente. Na primeira dessas tentativas, o presidente Hans Burggraaff teve papel de liderança, no início dos anos 1980 (CZ 2007, cap. 7). Como hoje em dia, havia controvérsias sobre quem deveria exercer o controle do normalizador internacional.

Desde 1973, a equipe administrativa e técnica do IASC foi liderada por uma série de secretários, destacados (i. e., emprestados pelos seus empregadores) por dois anos cada. O último deles foi Geoffrey Mitchell, destacado como secretário, que posteriormente se tornou o primeiro secretário-geral, após a criação dessa nova posição em 1984 e a desistência do título de secretário ${ }^{6}$. Em 1985, David Cairns assumiu a função de secretário-geral. Seu desempenho nessa posição foi admirável e nela permaneceu até 1994. A equipe técnica seguiu em quantidade limitada, já que o esboço das normas era realizado, principalmente, pelos comitês (CZ 2007, pp. 74-77).

\section{1987-2000: DESENVOLVIMENTOS NO IASC E ALÉM}

\subsection{O Impacto do IOSCO no IASC}

A International Organization of Securities Commissions (IOSCO) é uma confederação de reguladores do mercado de valores mobiliários. A sede da IOSCO, localizada originalmente em Montreal, mudou-se para Madri em 2000/2001. Fundada como órgão internacional em 1983, a IOSCO continuou praticamente desconhecida até 1987, quando a SEC e a Comission des Opérations de Bourse (COB) francesa, seu regulador da bolsa de valores, tornaram-se membros ativos e, assim, aumentaram a importância do órgão aos olhos dos reguladores ao redor do mundo. De sua parte, a SEC esperava que a IOSCO convencesse os reguladores a tomar medidas contra o abuso de informações privilegiadas e, ainda, contra a qualidade variável das práticas globais de contabilidade e auditoria. Desde 1987, a SEC tem sido a voz mais influente dentro da organização. De fato, desde 1990, quando a IOSCO criou um grupo de trabalho (agora denominado co- mitê) sobre informações multinacionais e contabilidade, este último sempre tem sido presidido por um membro sênior da SEC, da Divisão de Finanças Corporativas ou do Escritório do Contador Chefe. Além disso, um Comissário da SEC sempre tem sido membro e, uma vez, presidente, do poderoso Comitê Técnico da IOSCO, incluindo representantes dos 13 maiores mercados de capitais do mundo.

No ano de 1987, quando as lideranças do IASC estavam ficando impacientes com sua falta de maior impacto no mundo desenvolvido, a IOSCO contatou o IASC com uma proposta sedutora: se o conselho fosse aprimorar significativamente suas normas, a IOSCO, enfim, consideraria endossá-las para o uso de seus membros reguladores. As lideranças do IASC ousaram esperar que, um dia, a aprovação de suas normas pela IOSCO pudesse incitar a SEC a desistir de sua exigência de conciliação imposta a emitentes estrangeiros que utilizavam as IAS. 
A chamada da IOSCO pelas seguintes revisões nas normas do IASC poderia muito bem ter originado-se na própria SEC (International Organization of Securities Commissions, 1988, p. 8):

\section{Eliminar as alternativas contábeis}

Garantir níveis suficientes de detalhamento e abrangência Garantir que contenham exigências adequadas de divulgação

Em seguida, o IASC nomeou um comitê de "Comparabilidade" de alto nível, presidido por Ralph E. Walters e composto somente por membros do conselho, para propor reduções ou eliminações de opções, isto é, escolhas livres nas normas do IASC. O comitê realizou uma série de reuniões aceleradas e três representantes da IOSCO - os contadores-chefes da SEC, da COB e da Ontario Securities Commission - participaram como observadores e tiveram papel ativo nas discussões. O resultado dessas deliberações, com a aprovação final do conselho foi a declaração das intenções do IASC, intitulada Statement of intent: comparability of financial statements, publicada em julho de 1990, que marcou inúmeras alternativas contábeis para a eliminação de mais de uma dúzia de normas. Uma das eliminações acordadas foi o uso do UEPS como método de inventário aceitável. Em seguida, o conselho nomeou um comitê de "Melhorias", presidido por Paul G. Cherry, para propor revisões em dez de suas normas para satisfazer a IOSCO. O objetivo não era somente reduzir a quantidade de opções de acordo com o relatório do comitê de Comparabilidade, mas, também, garantir que as normas revisadas tivessem níveis suficientes de detalhamento e abrangência e exigências de informações adequadas. Essa foi uma tarefa intimidante para um comitê que atuava em tempo parcial. Apesar disso, ele cumpriu a tarefa, que incluía assegurar as aprovações necessárias do conselho completo e, até o final de 1993, as dez normas revisadas foram submetidas à IOSCO para sua avaliação. A liderança durante as reuniões do conselho proveniente dos presidentes do IASC, Arthur R. Wyatt e, em seguida, Eiichi Shiratori, foi crucial para o êxito do projeto. O comitê sofreu um único revés. Apesar da recomendada eliminação do UEPS contar com o apoio da delegação norte-americana, essa mudança foi derrotada porque quatro outras delegações (Alemanha, Itália, Japão e Coreia) votaram a favor de sua continuação, impedindo, assim, uma maioria de 3/4 para aprovar a proposta de eliminação. Nesses quatro países, o UEPS era aceitável para fins do imposto de renda, e as informações contábeis naqueles países estavam vinculadas à tributação. Grupos industriais de lobbying podem ter pressionado suas delegações a não eliminar o UEPS das informações contábeis.

A reação da IOSCO às normas melhoradas do conselho representou uma grande decepção para o presidente Shiratori. A IOSCO considerou a maioria das dez normas aceitáveis, mas desejava mais melhorias nas outras. E queria ver normas sobre relatórios trimestrais, ativos intangíveis, ganhos por ação, benefícios aos empregados, a maioria dos instrumentos financeiros e questões de reconhecimento e mensuração para operações descontinuadas. O conselho, castigado por esse revés, acordou com a IOSCO o fornecimento de um conjunto de duas dúzias de normas "chave", apropriadamente melhores e mais abrangentes, até 1999. Esse era um pedido muito grande para um órgão que trabalhava em tempo parcial, apesar de ter uma equipe de pesquisa (até meia dúzia) que aumentava gradualmente, incrementada por empréstimos de profissionais do CICA e outras fontes durante os anos 19907. Sir Bryan Carsberg sucedeu David Cairns como secretário-geral em 1995, e Michael Sharpe, australiano, assumiu a presidência do IASC em 1996 e ambos se mostraram lideranças críticas em um momento crítico, quando o conselho trabalhava em ritmo frenético para completar seu projeto de normas-chave a tempo (CZ 2007, pp. 215, 233-237, 269-286 e 293-328).

\subsection{Evolução nas Delegações Representadas no Conselho}

Talvez parcialmente, por causa do amplo interesse que a SEC tinha no trabalho do IASC, por meio de sua participação ativa na IOSCO, o FASB aceitou o convite do IASC, em 1988, para enviar um convidado sem direito a voto e, posteriormente, observador, às reuniões do conselho: Raymond C. Lauver, seguido por James J. Leisenring e Anthony T. Cope. Após anos de indiferença perante o IASC, o FASB, com seu presidente Dennis R. Beresford, passou a ter ativo interesse em seu trabalho. De modo semelhante, antes do final dos anos 1980, a Comissão Europeia havia ignorado as normas do IASC. Contudo, em 1990, com Karel Van Hulle substituindo o anterior chefe da unidade que lidava com as questões contábeis, a comissão aceitou a solicitação do IASC para começar a participar das reuniões do conselho na condição de observador sem direito a voto.

A IOSCO começou a enviar uma delegação de observadores às reuniões do conselho em 1996, sempre incluindo pelo menos um oficial da SEC. Em 1997, uma delegação de observadores do Chinese Institute of Certified Public Accountants começou a participar das reuniões do conselho (CZ 2007, pp. 228-230). O claro progresso no trabalho do conselho e a atenção que estava recebendo da IOSCO estava começando a atrair o interesse de diversas partes. A equipe técnica também saiu fortalecida, com Liesel Knorr e James S. Saloman sendo indicados como diretores técnicos em 1994 e 1999, respectivamente.

A quantidade de delegações representadas no conselho aumentou de 14 para 16 até 1996. Coreia e Jordânia, sucedendo Nigéria e Taiwan, eram membros rotativos. Nos anos 1990, delegações da Nordic Federation of Public Accountants, da Índia (à qual se juntou subsequentemente o Sri Lanka) e da Malásia, e da Federation of Swiss Industrial Holding Companies, além de uma delegação de executivos financeiros, sucederam às delegações da Itália, Coreia e 
Jordânia, e todas permaneceram no conselho até 2000 (CZ 2007, pp. 220-225 e 506-512). Assim, até 1997, o conselho estava reunindo-se ao redor de uma mesa muito maior, com a participação de mais de 45 membros, além da equipe e inúmeros observadores, totalizando entre 60 e 70 participantes (Kirsch, 2006, pp. 370-373). Devido à necessidade de discutir e debater muitos esboços controversos de normas novas e revisadas a ser submetidas à IOSCO até 1999, o conselho realizou uma série exaustiva de nove reuniões durante um período total de 45 dias em 1997 e 1998 (CZ 2007, pp. 213-237). Já havia se tornado claro que tal órgão de grande porte trabalhando nesse formato em tempo parcial era difícil de justificar como normalizador eficaz.

\subsection{Ascensão do G4+1}

Em 1993-1994, 4 normalizadores anglo-americanos - do Reino Unido, dos EUA, do Canadá e da Austrália começaram a se reunir trimestralmente com suas equipes para cristalizar seus pensamentos sobre questões que esperavam ser tratadas no IASC. O grupo tornou-se conhecido como o G4+1, o 1 sendo 1 representante, geralmente o secretário-geral, do IASC, que participava na condição de observador. Os 4 normalizadores tinham arcabouços conceituais e culturas contábeis semelhantes e era muito mais fácil para eles falar sobre perspectivas somente entre eles que nas reuniões do conselho do IASC, com muitas delegações de países tendo orientações contábeis históricas muito diferentes ${ }^{9}$. Entre 1994 e 2000, o G4+1 publicou 12 artigos sobre os temas discutidos: hedge accounting, provisões, concentrações de atividades empresariais, leases, e pagamento com base em ações, entre outros. Em 1996, o normalizador da Nova Zelândia tornou-se o quinto membro do G4. Havia receio dentro do conselho do IASC de que o G4+1 representasse uma tentativa das normalizadores dos países anglo-americanos de dirigir as deliberações do IASC em direção às suas próprias soluções e que pudessem ter a ambição de competir com o IASC para se tornar o normalizador global (CZ 2007, pp. 443-446). Esta última possibilidade não era algo além da imaginação, já que os 5 normalizadores eram bem financiados e equipados e 2 deles, o FASB e o U.K. Accounting Standards Board, estavam localizados em 2 dos maiores mercados de capitais do mundo. Sir David Tweedie, do Reino Unido, James Leisenring, dos EUA, e Kenneth H. Spencer, da Austrália, se sucederam como presidentes do G4+1 e, como veremos adiante, os 3 se tornariam personagens-chave na organização do IASB a partir de 2000. Patricia L. O’Malley, do Canadá, também participou das reuniões do G4+1, e tornaria-se membro do IASB em 2001.

\subsection{A SEC Anuncia os Atributos que Busca nas Normas do IASC}

Em 1996, a SEC decidiu fazer seu primeiro pronunciamento público (i. e., não por meio do IOSCO) sobre os atributos que as normas do IASC devem ter para ser aceitáveis para a preparação das demonstrações financeiras nas ofertas transfronteiras. Em um comunicado à imprensa em 11 de abril de 1996, a SEC afirmou que as normas devem refletir "três elementos-chave":

- As normas devem incluir um conjunto-chave de pronunciamentos contábeis que constitui uma base contábil abrangente, geralmente aceita;

- As normas devem ser de alta qualidade - devem resultar em comparabilidade e transparência e devem proporcionar informações plenas; e

- As normas devem ser interpretadas e aplicadas com rigor (CZ 2007, pp. 331-335).

Esse foi o primeiro uso do termo "alta qualidade" na discussão de normas e do processo de normalização, um termo ampla e frequentemente evocado desde então. O objetivo da SEC era tornar conhecidos os atributos gerais que buscava ao participar da avaliação das normas-chave do IASC pelo IOSCO.

Em 1997, a mando do congresso, a SEC emitiu um relatório para o congresso sobre o progresso no desenvolvimento das IAS e sobre a perspectiva de seu possível uso futuro por emissores privados estrangeiros nas ofertas e arquivamentos nos mercados de capitais norte-americanos (CZ 2007, pp. 335-338).

\subsection{Europa Começa a Considerar a Contabilidade em Termos do Mercado de Capitais e Entusiasma-se com o IASC}

Em abril de 1996, o IASC acelerou repentinamente o prazo para a submissão de suas normas principais ao IOSCO, de 1999 para março de 1998. Quais fatores levaram o IASC a adotar essa mudança em um cronograma já apertado?

Desenvolvimentos importantes estavam ocorrendo no continente europeu, em especial na Alemanha, que inclinaram a Europa mais para a necessidade de normas contábeis em sintonia com as necessidades dos investidores no mercado de capitais. Até então, Alemanha, França e alguns outros países do continente ainda eram mais envolvidos na tradição de um modelo contábil modelado, principalmente, pelas restrições legais da tributação e pela determinação do dividendo a ser pago aos acionistas. O princípio difundido da prudência, ou conservadorismo, era inquestionável. Contudo, estavam ocorrendo mudanças nos mercados e nas instituições financeiros que desafiavam essa realidade.

Tradicionalmente, os denominados bancos universais ou empresariais eram membros dos conselhos de administração das multinacionais alemãs. Tinham uma participação acionária na empresa e os bancos estavam prontos para fornecer os empréstimos necessários. Portanto, as empresas não tinham de depender do mercado acionário para financiamento, a não ser de modo limitado. Entretanto, com a reunificação da Alemanha, em 1990, os principais bancos alemães buscavam diversificar em busca das atividades bancárias de investimento e algumas multinacionais 
chegaram a ultrapassar o financiamento bancário. O efeito desses desenvolvimentos foi que não se podia depender tão facilmente do financiamento bancário como antes.

Em 1993, a parede sólida das multinacionais alemãs que se recusaram a ser negociadas na Bolsa de Nova York e, portanto, a ser exigidas a preparar outro conjunto de declarações consolidadas para conciliar seus ganhos com o patrimônio líquido aos US GAAP, como exigido pela SEC, rompeu-se quando Daimler-Benz, a maior empresa europeia, anunciou sua negociação em Nova York. Sua conciliação, referente a 1993, mostrou que seu lucro consolidado de 0.6 bilhões de marcos alemães, de acordo com os GAAP alemães, transformou-se em uma perda de 1,8 bilhão de marcos alemães sob os US GAAP, aparentemente porque a empresa havia lançado "reservas ocultas" que tinham o efeito de aumentar seus ganhos. Segundo Berger (2010, p. 16): "Indiscutivelmente, os resultados pelos US GAAP refletiam melhor a situação econômica. Os GAAP alemães perderam aceitação como normas contábeis". As outras multinacionais, como a Daimler, foram pressionadas a abandonar os desacreditados GAAP alemães e, no lugar deles, adotar os US GAAP ou as IAS, como fez uma série delas (como visto adiante). As empresas alemãs estavam buscando alívio regulatório da obrigação de preparar suas demonstrações contábeis consolidadas mediante o uso dos GAAP alemães. O governo federal respondeu com a aprovação do Kapitalaufnameerleichterungsgesetz (Lei de Alívio da Obtenção de Capital) em 1998, para permitir que as empresas alemãs preparassem suas demonstrações contábeis consolidadas de acordo com as normas contábeis internacionalmente aceitas, isto é, os US GAAP ou as IAS (Berger 2010, p. 17).

A Daimler continuou a demonstrar sua conciliação entre os GAAP alemães e os US GAAP em 1994 e 1995, até descobrir, em 1996, que a lei alemã regulava somente o arquivamento dos relatórios anuais (publicação no diário oficial), não o relatório anual enviado aos acionistas. Para aquele ano, a Daimler emitiu um relatório anual aos acionistas com suas demonstrações contábeis consolidadas totalmente em US GAAP.

Além disso, a recém-privatizada Deutsche Telekom marcou o lançamento de uma oferta pública inicial (IPO) de suas ações para 1996, 1/4 das quais tinha como destino os EUA. A IPO de US\$ 13 bilhões foi a maior da história da Europa. Após seu lançamento bem-sucedido em novembro de 1996, cerca de 2 milhões de compradores eram famílias alemãs. Para a surpresa de muitos nos mercados financeiros, verificou-se a existência de um mercado de ações de varejo na Alemanha.

No início de 1997, a bolsa alemã estabeleceu o Neuer Markt (Novo Mercado) para novas empresas de alta tecnologia e exigiu que estas, a maioria alemã, utilizassem os US GAAP ou as IAS, mas não os GAAP alemães.

É claro que a Comissão Europeia estava seguindo de perto esses desenvolvimentos e logo se entusiasmou com as normas do IASC como possível alternativa às Diretrizes Societárias contábeis, que enfocavam a reforma da lei societária e não a divulgação de informações úteis aos investidores no mercado de capitais. Gradualmente, a questão da emissão de regras contábeis em uma série de países continentais passou a envolver não só o Ministério da Justiça, responsável pela lei societária, mas, também, o Ministério de Finanças, preocupado com os mercados. Em sentido mais amplo, começou a aumentar na UE o interesse na criação de um mercado de capitais capaz de competir de igual para igual com mercados de capitais de outros lugares no mundo (CZ 2007, pp. 314-316, 328-331, 411-414 e 418-426). Por todos esses motivos, a liderança do IASC acreditava que o conselho tinha de preparar suas normas principais para o IOSCO até antes do planejado.

Essas mudanças fundamentais na cultura contábil e financeira, em sua velocidade de chegada, não foram digeridas com facilidade pelos membros da delegação alemã ao conselho do IASC, que estavam esforçando-se para acompanhar a nova realidade contábil de seu país. As delegações de outros países da Europa continental podem muito bem ter enfrentado um desafio semelhante (CZ 2007, pp. 227-228).

\subsection{O Conselho Completa as Principais Normas}

O conselho e sua equipe trabalharam incansavelmente entre 1994 e 1998 para completar o trabalho das outras normas principais. Enfim, em dezembro de 1998, o conselho aprovou a IAS 39, sobre instrumentos financeiros, a mais controversa das normas, quase completamente baseada nos US GAAP. Era para ser apenas uma solução interina. O conselho vinha tentando, desde 1989, desenvolver sua própria abordagem fundamental à norma, mas, no final, com a aproximação da data-limite de 1998, acabou decidindo buscar nos US GAAP a resposta. O conselho não cumpriu sua data-limite de março de 1998 por 9 meses e, com a IAS 39, o conjunto total das normas principais foi completado e imediatamente transmitido ao IOSCO, onde o grupo de trabalho sobre divulgação e contabilidade multinacionais iniciou o detalhado processo de avaliação da sua qualidade (CZ 2007, pp. 340-341, cap. 11).

\subsection{Mais Multinacionais Passam a Adotar as IAS}

Entre 1987 e 2000, uma série de multinacionais europeias passou a adotar preferencialmente as IAS em vez de seus GAAP nacionais, talvez com desvios, em suas demonstrações contábeis consolidadas. Exemplos foram as suíças Nestlé, Holderbank/Holcim, Roche, Ciba-Geigy/ Novartis e UBS e as alemães Schering, Heiderberg Zement, Bayer, Hoechst e Deutsche Bank. Nos EUA, várias grandes corporações começaram a firmar a conformidade de suas demonstrações às IAS: CPC International, Salomon Inc. e Microsoft. Além disso, os auditores da Salomon e Microsoft, Arthur Andersen \& Co. e Deloitte \& Touche, respectivamente, afirmaram em seus relatórios que as demonstrações das empresas foram uma apresentação fiel em conformidade com os US GAAP e as IAS, talvez as únicas ocasiões em que os Big 6 (ou Big 8) dos EUA fizeram tal afirmação antes do ano 2000. Uma afirmação semelhante foi feita por uma pequena empresa de auditoria nos relatórios anuais da International Federation of Accountants (CZ 2007, pp. 156-157 e 330). 


\subsection{O IASC se Reestrutura: 1997-2000}

A liderança do IASC tinha motivos para acreditar que o IOSCO estaria pouco disposto a endossar suas normas, a não ser que fosse para se reestruturar de tal modo que os reguladores, inclusive, particularmente, a SEC, pudessem confiar que o conselho, ao avançar, seria um normalizador de alta qualidade. Um órgão com atuação em tempo parcial com equipe relativamente pequena, com comitês voluntários responsáveis por esboçar as normas, com reuniões em plenário nas quais entre 60 e 70 pessoas se reúnem ao redor de uma enorme mesa não estabelece confiança. Portanto, o IASC criou um Grupo de Trabalho Estratégico, com o presidente e vice-presidente do conselho, outro membro do conselho (David Tweedie) e os principais representantes dos interesses da profissão contábil, da comunidade financeira, do setor empresarial e dos reguladores. O grupo foi presidido por Edward J. Waitzer, um advogado e ex-presidente imediato da Ontario Securities Commission (OSC) ${ }^{10}$. O grupo de trabalho recebeu a tarefa de propor um normalizador mais eficaz.

Após mais de 12 meses de frequentes reuniões, durante as quais debatia propostas para diferentes níveis de engajamento por órgãos contábeis e normalizadores nacionais em várias versões de uma estrutura normalizadora, o grupo de trabalho quase parecia ter alcançado um impasse entre abordagens rivais. Então, em setembro de 1999, o contador-chefe da SEC, Lynn E. Turner, enviou uma carta ao grupo de trabalho, informando a insistência da SEC de que o órgão reestruturado, para ter "autoridade e legitimidade", fosse relativamente pequeno, independente, com atuação em tempo integral, assistido por uma grande equipe de pesquisa e com procedimentos sólidos e transparentes. O principal critério de associação ao conselho, segundo a SEC, foi conhecimento técnico, não origem geográfica. Sem especificá-lo na carta, a SEC defendeu um órgão semelhante ao FASB.

Vozes no continente europeu, em especial a da Comissão Europeia, defendiam um órgão maior, com pelo menos algumas pessoas trabalhando em tempo parcial e alguma representação geográfica dos países comprometidos com a aplicação das normas.

Na reunião do conselho do IASC em novembro de 1999, quando se determinou o desenvolvimento de um plano de reestruturação, o conselho, apesar de continuar dividido sobre a melhor forma, decidiu com relutância, porém de modo unânime, aprovar uma reestruturação das linhas das demandas da SEC. Para o conselho, era impensável que um normalizador global não tivesse o apoio do país cujo mercado de capitais era o maior do mundo.

A seguir, o grupo de trabalho elaborou os detalhes da nova estrutura. Um conselho diretor de 19 membros "com diferentes características geográficas e funcionais"11 supervisionaria o conselho reestruturado. Os curadores (1) levantariam os fundos; (2) indicariam os membros do conselho, um comitê de interpretações (sucessor de outro estabelecido pelo IASC em 1997) ${ }^{12}$, e um Standards Advisory Council; e (3) monitorar a eficácia do conselho. A "principal qualificação para associação ao conselho seria o conhecimento técnico" e a "seleção dos membros do conselho não seria baseada em representação geográfica". O conselho teria 12 membros em tempo integral e 2 em tempo parcial; 7 dos 14 membros do conselho teriam de possuir vínculos formais com normalizadores nacionais, "que assistiriam o IASC no alcance da convergência das normas contábeis com soluções de alta qualidade". O grupo de trabalho declarou que "uma equipe técnica de alta qualidade com 15 pessoas é considerado um número inicial razoável". O conselho aprovaria suas decisões sobre questões técnicas por maioria simples. O secretário-geral supervisionou a elaboração de uma constituição baseada no relatório final do grupo de trabalho e o conselho do IASC a aprovou por unanimidade em sua reunião de março de 2000. Em maio de 2000, todos os órgãos membros do IASC - 143 órgãos contábeis profissionais em 104 países - aprovaram a reestruturação, inclusive a nova constituição, tornando-a definitiva. Por meio dessa decisão, a profissão contábil global cedeu sua "propriedade" do IASC ${ }^{13}$.

O grupo de trabalho determinou que um comitê de nomeação de 5 a 8 "indivíduos notáveis com diferentes características geográficas e funcionais" selecionasse os curadores iniciais. O comitê poderia "incluir membros sêniores de órgãos reguladores, grandes organizações internacionais, grandes corporações globais e a profissão contábil" (parágrafo 21). O conselho do IASB aprovou um comitê de 7 membros, inclusive o presidente da SEC, Arthur Levitt, selecionado pelo comitê como seu presidente. Os outros membros foram o presidente do Banco Mundial, os presidentes do COB francês, da Financial Services Authority do Reino Unido e da Securities and Futures Commission de Hong Kong, o principal executivo da Deloitte Touche Tohmatsu e o vice-presidente do Accounting Standards Board alemão ${ }^{14}$. O comitê, e particularmente Levitt, acreditava que os curadores exigiam uma pessoa de renome internacional para ser presidente do conselho diretor, e conseguiram recrutar Paul A. Volcker, ex-presidente do U.S. Federal Reserve Board, para a posição. Os outros 18 curadores eram indivíduos notáveis do mundo inteiro. A primeira reunião do conselho diretor foi realizada em junho de 2000, e Volcker selecionou Kenneth Spencer, da Austrália, 1 dos 3 contadores qualificados no conselho, para liderar o comitê de nomeação dos curadores. Spencer havia sido presidente do G4+1 e havia sido membro da delegação australiana no conselho do IASC em 2 ocasiões.

\footnotetext{
Por muito tempo, a SEC considerou a OSC como regulador que compartilha seus valores e crenças sobre questões de contabilidade e divulgação. 0 grupo de trabalho do IOSCO sobre divulgação e contabilidade multinacionais, como observado, sempre foi presidido por um oficial sênior da SEC, e sempre foi conveniente ao presidente que seu subcomitê de contabilidade e auditoria fosse presidido pelo contador-chefe da OSC ou seu vice. Assim, à medida que a SEC pode ter sido consultada acerca da seleção do presidente do Grupo de Trabalho Estratégico, a escolha do ex-presidente imediato da OSC seria bem-vinda. As citações neste parágrafo foram extraídas dos parágrafos 19(a), 19(b) e 64 do relatório do grupo de trabalho, Recommendations on Shaping IASC for the Future (1999). A referência ao parágrafo 21 no próximo parágrafo foi extraída da mesma fonte.

O Standing Interpretations Committee do IASC foi renomeado International Financial Reporting Interpretations Committee (IFRIC), em 2002, e, em 2010, foi renomeado IFRS Interpretations Committee. Uma cessão semelhante da propriedade da profissão contábil do normalizador nacional ocorreu nos EUA em 1973, quando o FASB sucedeu o Accounting Principles Board, e no Reino Unido em 1990, quando o Accounting Standards Board sucedeu o Accounting Standards Committee.

O Accounting Standards Board da Alemanha havia sido criado em 1998.
} 
Entre 1973 e 2000, mais de 200 indivíduos altamente qualificados, com diversas trajetórias profissionais, serviram em 22 delegações o conselho do IASC, assistidos por uma equipe talentosa e grupos de voluntários dedicados de todo o mundo, que elaboraram os documentos preliminares como membros dos comitês. Essa foi uma colaboração global realmente sem precedentes entre os profissionais contábeis. Nesse período, o IASC realizou 87 reuniões em 37 cidades ao redor do mundo e emitiu um arcabouço conceitual, 41 normas e 24 interpretações. Também publicou um periódico, o IASC Insight (CZ 2007, cap. 13, pp. 238-240 e 504-526).

\section{Exposição 1}

\section{International Accounting Standards Board (membros originais)}

Presidente: Sir David Tweedie - ex-presidente do Accounting Standards Board (Reino Unido)

Vice-presidente: Thomas E. Jones - ex-vice-presidente executivo, Citigroup (EUA)

Mary E. Barth (tempo parcial) - professor de contabilidade na Stanford University (EUA)

Hans-Georg Bruns (vínculo com normalizador alemão) ex-diretor contábil, Daimler/Chrysler (Alemanha)
Anthony T. Cope - ex-membro do Financial Accounting Standards Board (EUA)

Robert P. Garnett - ex-vice-presidente executivo de finanças, Anglo American plc (África do Sul)

Gilbert Gélard (vínculo com normalizador francês) - ex-sócio da KPMG, Paris (França)

Robert H. Herz (tempo parcial) - sócio técnico da PricewaterhouseCoopers, Nova York (EUA)

James J. Leisenring (vínculo com o FASB) - ex-vice-presidente do FASB (EUA)

Warren McGregor (vínculo com normalizador australiano e neozelandês) - ex-diretor executivo do Australian Accounting Research Foundation (Austrália)

Patricia O’Malley (vínculo com normalizador canadense) ex-presidente em tempo integral do Accounting Standards Board e ex-sócio técnico da KPMG, Toronto (Canadá)

Harry K. Schmid - vice-presidente sênior aposentado, Nestlé (Suíça)

Geoffrey Whittington (vínculo com normalizador britânico) - professor de contabilidade aposentado na Cambridge University e ex-membro do Accounting Standards Board (Reino Unido)

Tatsumi Yamada (vínculo com normalizador japonês) ex-sócio da ChuoAoyama Audit Corporation (membro da PwC), Tóquio (Japão).

\section{ORGANIZAÇÃO DO IASB EM 2000-2001}

O primeiro membro do conselho reestruturado a ser eleito foi seu presidente, David Tweedie, que presidia em tempo integral o UK Accounting Standards Board desde 1990, ele era membro da delegação britânica ao conselho do IASC desde 1995, originador e primeiro presidente do G4+1. Os curadores escolheram os outros 13 membros após extensa busca de candidatos e entrevistas. Não estabeleceram quotas formais de países ou regiões para a associação ao conselho. A composição geográfica resultante foi: 5 membros dos EUA, 2 do Reino Unido e 1 da Austrália, do Canadá, da França, da Alemanha, do Japão, da África do Sul e da Suíça, cada. Era um conselho composto por profissionais de alto gabarito. (Ver Exposição 1 com a lista dos membros do conselho inicial.) $\mathrm{O}$ contingente americano no novo conselho do IASC poderia contar com 5 dos 14 votos, desde que todos chegassem a um consenso, contra somente 1 dos 16 votos no conselho antigo. A pesada representação dos países anglo-americanos foi devidamente registrada, e não de forma positiva, no continente europeu; 9 dos 14 votos, 1 a mais de uma maioria simples, seriam concedidos pelos 5 dos $\mathrm{EUA}^{15}$, os 2 britânicos, 1 canadense e 1 australiano. Grande parte do conselho inicial consistia em "técnicos"16 e ex-normalizadores nacionais. Jim Leisenring e Tony Cope haviam trabalhado no FASB, David Tweedie e Geoffrey Whittington haviam sido o presidente em tempo integral e membro em tempo parcial, respectivamente, do
UK Accounting Standards Board e Tricia O’Malley havia sido presidente em tempo integral do Accounting Standards Board canadense. Warren McGregor foi, por longo período, o diretor da fundação de pesquisa que apoiava o Australian Accounting Standards Board. Whittington e Mary E. Barth eram professores de contabilidade. Hans-Georg Bruns havia sido o chefe de contabilidade da Daimler. Metade dos membros do conselho haviam sido sócios de auditoria de uma das 5 Grandes (ou 6 Grandes); 8 dos 14 membros haviam sido delegados ou observadores sem direito a voto no antigo conselho do IASC. Quatro membros haviam participado do G4+1. A socialização do novo conselho não foi nada difícil, considerando que a maioria dos membros já se conhecia.

A composição do conselho deveria incluir pelo menos 5 membros de empresas de auditoria, 3 de empresas e 3 da comunidade de usuários e pelo menos 1 acadêmico. $\mathrm{O}$ grupo mais difícil de recrutar eram o dos usuários, e havia dúvidas quanto ao fato de 2 dos 3 classificados como usuários serem membros daquela classe. Somente 1 dos 3 realmente havia sido usuário profissional do mercado de valores mobiliários durante bastante tempo.

Os curadores levantaram os fundos necessários das 5 grandes empresas de auditoria, empresas, instituições financeiras e bancos centrais, e o conselho, cujo nome foi alterado para Financial Accounting Standards Board (FASB), 
realizou sua primeira reunião oficial em abril de 2001. Suas normas, então, passariam a ser conhecidas como International Financial Reporting Standards (IFRS). Como antes, o conselho publicou documentos para debate e projetos, e logo começou a organizar mesas-redondas sobre projetos importantes. Ele seguiu um elaborado due process ${ }^{17}$.

\section{2000: O ANO DOS REGULADORES}

\subsection{O Comunicado de Conceito da SEC}

Em fevereiro de 2000 foi publicado um bem-sucedido comunicado de conceito sobre as Normas Internacionais de Contabilidade (Securities and Exchange Commission, 2000). Na publicação, elaborada pelo contador-chefe Lynn Turner e por sua vice Mary B. Tokar, a SEC formulou 26 questões de pesquisa acerca da qualidade e solidez das normas do IASC, o papel do auditor na aplicação das normas e o papel dos reguladores na interpretação e aplicação das normas. A SEC considerou que "as normas contábeis não só devem ser de alta qualidade, mas, também, devem ser apoiadas por uma infraestrutura que garanta sua interpretação e aplicação rigorosas". Os elementos daquela infraestrutura incluíam:

- normalizadores eficazes, independentes e de alta qualidade nas áreas de contabilidade e auditoria;

- normas de auditoria de alta qualidade;

- empresas de auditoria com controles de qualidade eficazes ao redor do mundo;

- garantia de qualidade na profissão como um todo; e

- supervisão regulatória ativa.

Essa foi, de fato, uma lista intimidante e alguns questionaram quando, se é que algum dia, toda a infraestrutura global prevista pela SEC estaria funcionando. Qualquer um que acreditava que a SEC pudesse, algum dia, desistir de sua exigência de reconciliação por parte dos emissores particulares estrangeiros mediante as IAS, mesmo se o IOSCO endossasse as normas principais do IASC, teria ficado desconcertado com as demandas estabelecidas nesse documento de discussão (CZ 2007, pp. 343-347)

\subsection{Aprovação do IOSCO}

Em maio de 2000, o comitê técnico do IOSCO, em resposta a um relatório favorável de seu grupo de trabalho sobre divulgação e contabilidade multinacionais, recomendou a seus membros reguladores que permitissem às empresas multinacionais utilizar as normas principais do IASC nas demonstrações financeiras empregadas em negociações e ofertas de valores mobiliários internacionais. Mesmo assim, condicionou esse conselho ao permitir que os reguladores impusessem três "tratamentos suplementares" ao lidar da sua própria maneira com as muitas "questões substanciais pendentes" nas normas principais listadas no relatório (IOSCO Technical Committee, 2000). Como resumiu o comitê dos presidentes do IOSCO, que ratificou o relatório do comitê técnico, os três tratamentos complementares eram os seguintes:

- conciliação: exigência de conciliação de determinados itens para mostrar o efeito da aplicação de um método contábil diferente, em contraste com o método aplicado sob as normas do IASC;

- divulgação: exigência de divulgações adicionais, na apresentação das demonstrações financeiras ou nas notas; e

- interpretação: especificação do uso de uma alternativa em particular oferecida em uma norma do IASC, ou uma interpretação particular em casos nos quais a norma do IASC é omissa ou pouco clara.

Esses foram os mesmos tratamentos que a SEC já utilizava ao revisar as demonstrações financeiras das empresas e sua inclusão no relatório do comitê técnico parecia significar que a conciliação exigida pela SEC para não usuários dos US GAAP também se aplicaria aos usuários das IAS. Portanto, havia quem considerasse a aprovação do IOSCO bastante "oca", mas esse ato de endossar, decerto, serviu para incrementar as credenciais globais do IASC como normalizador. Esse simbolismo não poderia ser negado. $\mathrm{O}$ grupo de trabalho do IOSCO, em seu relatório ao comitê técnico, identificou inúmeras questões que o IASB passou a tratar a partir de 2001, quando iniciou as melhorias herdadas do antigo IASC (CZ 2007, pp. 341-343).

\subsection{A Comissão Europeia Compromete-se com as IAS}

Em junho de 2000 ocorreu o desenvolvimento regulatório mais significativo do ano: a Comissão Europeia anunciou, para surpresa da maioria, sua estratégia revisada de que deveria ser exigida das empresas negociadas na UE a adoção das IAS em suas demonstrações consolidadas até 2005. O Council of Economic and Finance Ministers da UE aprovou imediatamente essa nova estratégia em julho. A comissão declarou que o objetivo central dessa estratégia "é que a política deveria garantir a possibilidade de negociação dos valores mobiliários nos mercados financeiros da UE e internacionais com base em um único conjunto de normas de divulgação contábil" (EU Financial Reporting Strategy: the way forward, 2000, parágrafo 7) ${ }^{18}$. Naquele momento, havia aproximadamente 6.700 empresas negociadas em bolsa nos 15 Estados membros da UE, 275 das quais alegavam já utilizar as normas do IASC. Desde meados dos anos 1990, quando a discussão havia se iniciado, de fato, na UE sobre a ne- 
cessidade de desenvolver seu mercado de capitais interno, a questão das práticas contábeis comparáveis que atenderiam às necessidades de informação dos pesquisadores surgiu como uma questão importante. Para ter certeza, os 15 GAAP nacionais na UE haviam tornado-se um tanto mais parecidos como resultado da incorporação pelos estados membros da Quarta e Sétima Diretrizes da Lei Societária sobre contabilidade em suas legislações nacionais, mas isso não bastaria.

Não eram "sistemas de divulgação contábil orientados ao investidor" (parágrafo 14), sintonizados com as necessidades de informação do mercado de capitais. As outras opções, além das diretrizes, eram os US GAAP e as IAS. Os US GAAP estavam fora de cogitação, por ser provenientes dos EUA e pelo excesso de volume e detalhamento. Além disso, haviam sido formulados pelo FASB, e qual interesse o FASB teria nas perspectivas europeias ao desenvolver suas normas? Pelo contrário, o IASC era um normalizador declaradamente internacional, sediado em Londres, e, decerto, incluiria diversos membros europeus após a reestruturação. A Comissão Europeia observou que, desde 1995, “o IASC empreendeu um processo de revisão gradual, mas aprofundado, de revisão de suas normas. As IAS já proporcionam um conjunto abrangente e conceitualmente sólido de normas de divulgação contábil que deveria atender às necessidades da comunidade empresarial internacional" (parágrafo 15). Isso constituía um apoio encorajador de um órgão que, apenas 15 anos antes, havia descartado as normas do IASC por considerá-las irrelevantes para a Europa.

Em maio de 2000, o conselho da UE havia se reunido em Lisboa, quando adotou um passo político importante em direção a um mercado integrado de serviços financeiros e de capitais na UE, enfim, até 2005. Portanto, o anúncio da Comissão Europeia em junho de 2000, como discutido, significou as implicações daquele passo para o papel do IASC e suas normas no desenvolvimento futuro da UE. Essa revisão significativa na estratégia da Comissão Europeia era de importância histórica para o IASC, que em breve se tornaria o IASB. Significou que o novo IASB teria garantido uma grande clientela para suas normas, porque nenhum outro país(es) do mundo desenvolvido tinha(m) anunciado um compromisso com as normas do IASC. Se o IASB tivesse iniciado suas operações em 2001 sem tal base de apoio, teria sido tão duradoura e significativa sua influência? Como veremos adiante, os países de outras regiões do mundo notaram o compromisso da UE e, portanto, passaram a considerar as normas do IASB muito mais como consequências que como mera extensão da série de normas voluntárias emitidas pelo antigo IASC (CZ 2007, pp. 430-432).

A estratégia revisada da Comissão Europeia impôs um dilema processual, porque não havia precedente nos EUA para o estabelecimento, de fato, de leis europeias por um órgão do setor privado. Para que as empresas europeias negociadas em bolsa fossem obrigadas a obedecer às IAS, tal exigência havia de ter a força das leis europeias. Por meio de um procedimento conhecido na UE como "comitologia", a Comissão Europeia montou um processo por meio do qual as normas do IASB pudessem ser endossadas para uso compulsório por empresas europeias negociadas em bolsa sem a necessidade de submeter cada norma ao Parlamento e ao Conselho Europeu para aprovação (Van Hulle, 2008). Primeiro, a Comissão Europeia instigou o setor privado a estabelecer um comitê de especialistas contábeis baseados na UE que pudesse fornecer feedback técnico ao conselho do IASB no desenvolvimento de suas normas e interpretações e depois pudesse aconselhar a comissão sobre a solidez técnica da norma ou as interpretações finais para uso obrigatório na UE. Esse órgão, estabelecido em 2001, foi denominado European Financial Reporting Advisory Group (EFRAG), que evoluiu para um comentarista proativo das normas contábeis na Europa (Enevoldsen \& Oversberg, 2008). O Technical Expert Group (TEG) do EFRAG possui uma dúzia de membros votantes, representando uma série de características profissionais e geográficas, que discutem os projetos do IASB e aconselham a Comissão Europeia quanto à qualidade técnica de suas normas e interpretações finais. Segundo, a comissão criou um Accounting Regulatory Committee (ARC) com representantes de todos os governos dos Estados membros. Após a comissão receber uma avaliação positiva em nível técnico do TEG, submete a norma ou interpretação ao ARC para avaliação de sua aceitação "política".

Porque um ou mais governos dos Estados membros se pronunciaria sobre a aceitação "política" de uma norma ou interpretação? No processo de elaboração do IASB, empresas, bancos, associações de negócios ou grupos de investidores podem apresentar preocupações ao seu governo nacional de que a norma, se endossada, teria um custo alto demais para ser implementada ou traria consequências adversas para a economia nacional, tais como incentivos redutores das atividades empreendedoras. Em casos excepcionais, essas preocupações também podem ser formuladas aos membros do Parlamento Europeu. Até o momento, as queixas aos membros do Parlamento Europeu levaram à postergação do endosso de uma única norma, a IFRS 8, sobre segmentos operacionais (Roberts, 2010, pp. 465-469). O Parlamento tem o poder de postergar ou vetar um endosso de acordo com esse procedimento de comitologia, mas não pode, por si, tomar a iniciativa de endossar uma norma que a Comissão Europeia não submeteu a endosso. A própria Comissão Europeia postergou as ações sobre algumas normas e interpretações do IASB, porque um ou mais governos importantes da UE recusaram-se a fazer parte dele ${ }^{19}$. Em 7 de junho de 2002, a UE anunciou que o Parlamento e o Conselho Europeu haviam aprovado o Regulamento (EC) 1606/2002, conhecido como o Regulamento das IAS, implementando a estratégia revisada da Comissão Europeia e impondo a obrigação, à maioria das empresas negociadas em bolsa da EU, de iniciar a utilização das IAS/IFRS endossadas até $1^{\circ}$ de janeiro de 2005 (IAS Regulation 1606/2002, 2002) ${ }^{20}$.

Exemplos notáveis são a IFRIC 12, sobre acordos de concessão de serviços, de novembro de 2006, e a IFRS 9, sobre instrumentos financeiros, emitida em novembro de 2009. A IFRIC 12, enfim, foi endossada mais de dois anos após sua emissão, após a preparação e emissão pela Comissão Europeia de um estudo de impacto (disponível em http://ec.europa.eu/internal_market/accounting/docs/effect_study_ifric12_en.pdf).

Veja o comunicado da Comissão Europeia à imprensa disponivel em http://www.iasplus.com/resource/euiasregpr.pdf. O Regulamento IAS da UE também se aplica aos três membros da European Economic Area (Noruega, Islândia e Liechtenstein). Um número limitado de empresas negociadas em bolsa na UE, principalmente aquelas negociadas em New York, recebeu uma extensão até $1^{\circ}$ de janeiro de 2007. 
No início do próximo mês, o Financial Reporting Council (FRC) da Austrália anunciou que "formalizou seu apoio à adoção das normas contábeis internacionais até $1^{\circ}$ de janeiro de 2005" (Adoption of International Accounting Standards by 2005, 2002). No comunicado à imprensa do FRC, Jeffrey Lucy, o presidente do FRC declarou que "a Austrália definitivamente não pode se dar o luxo de ficar atrás da Europa nesse aspecto". O mundo havia começado a notar a implementação da estratégia revisada da Comissão Europeia.

Após o endosso de uma norma ou interpretação do IASB para uso compulsório por empresas negociadas em bolsa da UE, como a empresa e o auditor devem formular a afirmação de que as demonstrações financeiras estão de acordo com as normas endossadas? Em 2005, a Comissão Europeia, em consulta com o ARC, decidiu que a formulação exigida deve ser: "De acordo com as Normas Internacionais de Relatórios Financeiros, conforme adotadas pela UE" (Reference to the financial reporting framework in the
EU in accounting policies and in the audit report and applicability of endorsed standards, 2005). Essa decisão cria um problema para leitores que não sabem quais diferenças, se for o caso, existem entre as IFRS endossadas pela UE e as IFRS, conforme emitidas pelo IASB. Para que os leitores das demonstrações financeiras possam confiar na comparabilidade das IFRS entre os países, eles devem ser informados acerca de quaisquer diferenças salientes entre os arcabouços dos países para a elaboração dos relatórios financeiros. Como, então, um leitor em, digamos, Tóquio, Sydney ou Nova York, das demonstrações contábeis de uma empresa europeia negociada em bolsa, acompanhadas por tal declaração de conformidade, poderá saber se, e até que ponto, as demonstrações contábeis cumprem o conjunto completo das IFRS conforme emitidas pelo IASB? A UE não exige que as empresas informem os desvios das IFRS como emitido pelo IASB ${ }^{21}$. Esse dilema tornou-se uma preocupação para a SEC em 2007, como discutido na próxima seção.

\section{OS PRIMEIROS CINCO ANOS DO IASB: 2001-2006}

Uma das prioridades do IASB em 2001 e 2002 foi iniciar um processo de convergência mútua com o FASB, de tal modo que, após a quase compatibilidade dos dois conjuntos de normas, a SEC pudesse quase desistir de sua exigência de conciliação para emissores privados estrangeiros que utilizam os IFRS (Pacter, 2005). Como contemplado pela liderança do antigo IASC, já em 1987, a desistência pela SEC de sua exigência de conciliação também era a principal perspectiva nas mentes da liderança do conselho do IASB. De sua parte, a SEC estimulou ambos os conselhos a diminuir as diferenças entre suas normas. Quando Robert Herz se demitiu do IASB, em junho de 2002, para se tornar o presidente do FASB, a oportunidade de consolidar esse relacionamento havia chegado. Em outubro de 2002, após a primeira reunião conjunta formal entre os dois conselhos, o IASB e o FASB emitiram um memorando de entendimento (MdE) conhecido como o "Acordo de Norwalk", que afirmou seu compromisso de "tornar suas normas para a elaboração dos relatórios financeiros existentes totalmente compatíveis no menor prazo praticável”. Prometeram progresso em projetos não especificados de curto prazo, que poderiam ser completados nos próximos anos, além da coordenação de seus futuros programas de trabalho para projetos de maior prazo $^{22}$. Em fevereiro de 2006, ambos os conselhos firmaram outro MdE para esboçar seu futuro progresso de convergência mútua em uma série de normas principais $^{23}$. Esse MdE foi atualizado em 2008 e estabeleceu uma meta de término até $2011^{24}$, e, em 2009, os dois conselhos anunciaram publicamente um prazo acelerado para completar os projetos do $\mathrm{MdE}^{25}$.

\subsection{A Agenda de Projetos do IASB}

Em 2001, o conselho do IASB decidiu sobre uma agenda ambiciosa de projetos, inclusive o pagamento baseado em ações, combinações de negócios, contratos de seguros, relatórios de desempenho e melhoria da IAS 39. Outra prioridade do conselho foi a melhoria das outras normas herdadas do IASC para lidar com as muitas questões levantadas pelo grupo de trabalho do IOSCO em sua recomendação ao comitê técnico, que levou ao endosso pelo IOSCO em 2000.

$\mathrm{O}$ pagamento baseado em ações era um projeto controverso porque as multinacionais europeias não queriam ver-se em desvantagem competitiva perante empresas que não tinham a obrigação de custear as opções de ações pelos US GAAP (Zeff, 2010, pp. 266-267). Apesar dessa controvérsia, o IASB conseguiu emitir a IFRS 2, em fevereiro de 2004. Exigiu que as despesas apareçam na demonstração dos resultados e seguiu de perto o projeto do FASB emitido em 1993 (solução preferida do FASB), que o FASB não conseguiu incorporar à SFAS 123 em 1995, devido à intensa oposição política (Zeff, 1997). Em 2002, logo após o IASB ter começado a trabalhar no pagamento baseado em ações, o FASB retomou o assunto. Apesar do tratamento contábil das opções de ações dos empregados seguir sendo fonte de grande discussão nos EUA, com membros do Congresso ameaçando impedir o FASB (Zeff, 2002, pp. 44-45; Zeff, 2010, pp. 272-274), o FASB, mesmo assim, explorou o precedente do IASB e emitiu a SFAS $123 \mathrm{R}$ nas mesmas linhas que a IFRS 2, exigindo o custeio das opções de ações. A IFRS 2 realmente foi um dos sucessos do IASB.

\footnotetext{
21 Em seu comunicado no qual transmitiu a notícia da decisão da Comissão Europeia sobre a formulação exigida a ser adotada por empresas e auditores, a Fédération des Experts Comptables Européens (FEE) "estimulou fortemente" as empresas a incluir uma explicação nas notas às demonstrações contábeis sobre quaisquer diferenças entre suas politicas contábeis e IFRS como emitidas pelo IASB. A FEE também recomendou que as empresas europeias negociadas em bolsa afirmassem seu cumprimento com as IFRS completas (Reference to the financial reporting framework in the EU in accounting policies and in the audit report and applicability of endorsed standards, 2005). Essas recomendações também deveriam aplicar-se ao relatório da auditoria. Contudo, a Comissão Europeia não reiterou essas recomendações Alguns auditores de empresas europeias, na verdade, deram essa segunda opinião, sobre o cumprimento com as IFRS completas, em seus pareceres (Nobes $\&$ Zeff, 2008).

22 Para o texto do acordo, ver http://www.fasb.org/news/memorandum/pdf. Entre os projetos de curto prazo lançados na sequência do Acordo de Norwalk, havia projetos sobre impostos de renda, uma revisão da IAS 37, sobre provisões, da IFRS 5, sobre ativos não circulantes mantidos para venda e operaç̃es descontinuadas, e a apresentação das demonstraç̃es contábeis.

23 Verhttp://www.fasb.org/cs/

24 Verhttp://www.fasb.org/intl/MOU_09-11-08.pdf.

5 Verhttp://www.fasb.org/cs/ContentServer?c1/4Document_EGpagename1/4FASB\%2FDocument_C\%2FDocumentPageE cid1/41176156245558.
} 


\subsection{A controvérsia sobre a IAS 39}

Em dezembro de 2003, o conselho emitiu as normas aprimoradas que herdou do IASC, inclusive a IAS 39, sobre instrumentos financeiros. A IAS 39 foi altamente controversa, especialmente entre os grandes bancos franceses, pois nenhum deles aceitava que não poderia mais utilizar a contabilidade de cobertura com posições cobertas significativas. O IASB havia tentado responder a algumas de suas preocupações, mas foi feita uma emenda adicional sobre macrocobertura diante das conhecidas objeções remanescentes entre os bancos. Os grandes bancos, além do governo francês, não acreditavam que o IASB imporia sua independência apesar das consequências negativas de sua norma para os bancos. A tradição de longa data na França era que o normalizador contábil, baseado no Ministério de Finanças, era receptivo a questões de impacto comercial e política pública (Scheid \& Walton, 1992, cap.7). Na França, os grandes bancos têm o apoio do Presidente da República e, em julho de 2003, o Presidente Jacques Chirac externou sua visão de que a IAS 30 poderia trazer consequências "danosas" à estabilidade financeira na Europa (Veron, 2007, p. 36). A visão do presidente francês costuma ter peso nos corredores das decisões políticas europeias. Contudo, o IASB não cedeu em relação à norma, apesar dessa pressão política.

Houve uma crítica à IAS 39 proveniente do Banco Central Europeu (ECB). Este contestou a "aplicação integral do valor justo" para a mensuração dos ativos e passivos financeiros por seu valor justo. A principal preocupação do ECB foi o impacto potencial na estabilidade financeira que tal política contábil pudesse ter, tanto por causa de mudanças nas atividades comerciais dos bancos quanto por causa das alterações nas percepções públicas dos perfis de risco dos bancos. Mais especificamente, o ECB estava preocupado com a mensuração do passivo por seu valor justo, considerando particularmente que uma entidade em dificuldades financeiras, com uma notação de crédito que aumenta a taxa de juros para seus empréstimos, poderia, pela norma, balizar seu lucro declarado ao mostrar um ganho de posse não realizado sobre a dívida. O Banco sentia que esse resultado era incongruente. O IASB estava disposto a acomodar a preocupação do ECB, mas não conseguiu emitir uma emenda de modo rápido o suficiente antes da Comissão Europeia responder à norma completa. Em novembro de 2004, a comissão anunciou sua aprovação com exceções relacionadas a ambas as provisões contestadas: macrocobertura e a aplicação integral do valor justo. Esse foi um episódio embaraçoso para o IASB e, também, para a Comissão Europeia. Porém, considerava-se que as exceções influenciavam as demonstrações contábeis de somente 2 a 3 dúzias de bancos. Em agosto de 2005, o IASB emitiu uma emenda à IAS 39 para acomodar a preocupação do ECB, mas a outra exceção continua (ver Zeff, 2010, pp. 267-269) ${ }^{26}$.

\subsection{Empresas da UE Adotam as IFRS}

Em 2005, como planejado, a grande maioria das aproximadamente 8.000 empresas negociadas em bolsa na UE ampliada migraram de seus GAAP nacionais para as IFRS em suas demonstrações financeiras consolidadas. Sem dúvida, a comparabilidade além das fronteiras obteve um salto significativo. Em seu relatório sobre um grande estudo das demonstrações financeiras de 65 empresas sob as IFRS, a Ernst \& Young (2006, p. 6) escreveu: "A implementação das IFRS em 2005 foi um grande sucesso como um todo, com as empresas enfrentando o desafio de introduzir as alterações fundamentais na contabilidade e na divulgação contábil. Porém, observamos que, atualmente, as demonstrações contábeis pelas IFRS mantêm uma forte identidade nacional". As culturas contábeis têm raízes profundas, e velhos hábitos não mudam facilmente (ver Nobes, 2011).

\subsection{A Revisão Constitucional do Conselho Diretor em 2005}

A composição bastante "técnica" do conselho diretor, além da experiência exasperada do conselho com a IAS 39, levou os críticos a se queixar que o conselho é excessivamente teórico e não escuta. Em 2005, os diretores da Fundação IASC realizaram sua revisão constitucional quinquenal e adotaram algumas mudanças em resposta aos críticos. Primeiro, substituíram o "conhecimento técnico especializado" como principal critério de inclusão no conselho pela "competência profissional e experiência prática". Segundo, alteraram a maioria exigida para a aprovação das normas de $8 \times 6$, uma maioria simples, para $9 \times 5$, um a mais do que uma maioria simples $^{27}$. Essa última mudança parece ter exercido um impacto comparativamente limitado no comportamento do conselho. A primeira mudança, porém, pode ter sido relevante na mudança gradual nas características representadas no conselho. Com a aposentadoria dos membros iniciais do conselho, foram sucedidos por membros com um histórico técnico menos acentuado e, também, com menor experiência preliminar de normalização. Desde 2001, é claro, teriam ocorrido menos oportunidades de ganhar experiência nacional na área de normalização, exceto no FASB, no Accounting Standards Board of Japan e alguns poucos órgãos desse tipo. Até o final da década, os membros do conselho incluíram mais usuários genuínos, além de vários antigos reguladores entre seus membros, e poucos eram "técnicos". De fato, em julho de 2011, Hans Hoogervorst, ex-presidente imediato do regulador holandês de valores mobiliários, que não tem histórico contábil, sucedeu David Tweedie como presidente do IASB.

\subsection{Evolução da Equipe Técnica}

A quantidade de profissionais técnicos e de pesquisa do IASB aumentou constantemente desde 2001 e tornou-se cada vez mais internacional, alcançando 56 em maio de 2011: 8 dos EUA, 7 da Alemanha e do Reino Unido, cada, 4 da Austrália, Japão e África do Sul, cada, e o restante proveniente de 15 países da Europa, África, Ásia e América do Norte ${ }^{28}$.

\footnotetext{
Para a história passo a passo das fases dessa controvérsia, ver as edições do World Accounting Report de 2003 e 2004

Os diretores da Fundação IASC não foram os únicos a modificar a maioria exigida para a aprovação das normas. Nos EUA, os diretores da Fundação FAF alteraram três vezes a maioria exigida com direito a voto para o FASB: de $5 \times 2$ para $4 \times 3$, em 1977, de $4 \times 3$ de volta para $5 \times 2$, em 1990 e novamente de $5 \times 2$ para $4 \times 3$, em 2002.
}

Comunicação com o autor enviada por Alan Teixeira, datada de 20 de maio de 2011. 
No início desse período, a SEC estimulou duas vezes o renome das IFRS no mercado de valores mobiliários dos EUA e o AICPA concedeu ao IASB um voto de confiança. Esses desenvolvimentos foram seguidos em 2008 pelas nuvens escuras da crise econômica e financeira.

\subsection{Ações pela SEC e AICPA}

Os principais desenvolvimentos externos que influenciaram o trabalho do conselho em 2007 foram, provavelmente, decisões tomadas na SEC. Em abril de 2005, o contador-chefe do SEC, Donald T. Nicolaisen, havia proposto um possivel "mapa do caminho" para abandonar a exigência de conciliação para os emissores particulares estrangeiros que utilizavam as IFRS (Nicolaisen, 2005). Apesar de ele abraçar somente seus pontos de vista pessoais, essa direção, aparentemente, tinha amplo suporte dentro da comissão. Entre outros fatores, a Europa pressionava para que a SEC finalmente se comprometesse com as IFRS. Em julho de 2007, então, a SEC lançou uma proposta de norma para abandonar a exigência de conciliação para os emissores particulares estrangeiros que adotavam "as IFRS conforme publicados pelo IASB” e, em 15 de novembro de 2007, a comissão unânime aprovou a regra, para entrada em vigor imediata $^{29}$. A rapidez com que a SEC adotou essa regra surpreendeu muita gente, inclusive no IASB. Havia uma ideia crescente na comissão de que a nota de conciliação às demonstrações financeiras não continha informações úteis aos investidores (Walton, 2009, pp. 12-13).

Também em 2007, a SEC lançou um documento de discussão para explorar a possibilidade de permitir que os usuários dos EUA utilizassem as IFRS em suas submissões à comissão ${ }^{30}$. Antes da publicação desse documento, poucos acreditavam que, um dia, a SEC iria tão longe em direção ao possível uso das IFRS pelas empresas norte-americanas. Então, em agosto de 2008, a SEC aprovou, de modo unânime, com o apoio entusiasmado de todos os seus escritórios e divisões participantes, uma proposta de norma com um mapa do caminho para a eventual adoção compulsória das IFRS pelos emissores norte-americanos ${ }^{31}$. Esses desenvolvimentos em 2007, inclusive o abandono da exigência de reconciliação, e em 2008 foram impulsionados por Christopher Cox, presidente da SEC. Entretanto, diante da crise econômica e financeira emergente no sistema econômico e político dos EUA, a nova presidente da SEC, Mary L. Schapiro, que sucedeu Cox em janeiro de 2009, testemunhou em sua audição de confirmação que não se sentiu obrigada pelo mapa do caminho (New Chairman Appointed, 2009).

Desde 2009, a equipe contábil da SEC vinha sugerindo um processo denominado "condorsement", que, essencialmente, refere-se à convergência gradual com as IFRS a ser projetada pelo FASB, como possível caminho (Beswick, 2010; Work plan for the consideration of incorporating international financial reporting standards into the financial reporting system For U.S. issuers: exploring a possible method of incorporation, 2011). A SEC havia prometido exprimir sua posição perante as IFRS até o final de 2011, porém, agora se espera que anunciará sua posição em 2012.

O AICPA anunciou uma decisão em maio de 2008 que tornou os EUA o primeiro país onde as empresas com capital fechado podem adotar as IFRS antes das empresas negociadas em bolsa. O conselho diretor do AICPA designou o IASB como órgão contábil para fins de elaboração de princípios de contabilidade e divulgação internacionais, proporcionando, assim, aos membros do AICPA a opção de realizar as auditorias de acordo com as IFRS, como alternativa aos US GAAP, segundo as Regras 202 e 203 do Code of Professional Conduct (AICPA Council, 2008). Portanto, as empresas com capital fechado com sede nos EUA subsidiárias de matrizes estrangeiras que utilizam as IFRS também podem adotar as IFRS em suas demonstrações financeiras auditadas.

\subsection{Impacto da Crise Econômica e Financeira}

Em outubro de 2008, a crise econômica e financeira invadiu repentinamente o mundo do IASB (ver Meltdown at the IASB?, 2008). Os preços do mercado dos valores mobiliários haviam desabado no terceiro trimestre do ano e os bancos que haviam classificado suas posições de títulos de dívida como negociáveis desesperaram-se com a perspectiva de registrar gigantescas perdas de posse não realizadas em seus ganhos trimestrais. Apesar de as IFRS não permitirem às empresas reclassificar títulos em uma carteira de negócios, os US GAAP permitiam tal reclassificação, mas somente em circunstâncias muito raras. Contudo, os bancos europeus se queixaram de estar em desvantagem competitiva nesse sentido perante aquelas empresas que utilizavam os US GAAP, e pressionaram o IASB a conceder aos usuários das IFRS a oportunidade de reclassificar suas posições de dívida de "negócio" para "posse até o vencimento". Quando os títulos de dívida são classificados como "posse até o vencimento", não haveria necessidade de registrar nenhum ganho ou perda não realizado(a) (a não ser que haja um prejuízo). A Comissão Europeia notificou o IASB de que devia emitir uma norma imediatamente, sem o due process, para autorizar tal reclassificação - senão, a comissão tomaria alguma ação não especificada, que poderia causar a perda pelo IASB de seu privilégio de normalizador contábil na UE. A questão tinha urgência, porque os bancos estavam prestes a lançar seus relatórios de ganhos do terceiro trimestre. Engolindo a seco, o IASB aprovou devidamente tal norma, de modo retroativo (como exigido pela comissão) até $1^{\circ}$ de julho de 2008, quando os valores de mercado de suas posições de dívida podem não ter sido inferiores (ou pelo menos não muito) aos valores escriturados. Foi um episódio bizarro e o presidente 
Tweedie afirmou que quase pediu demissão (Pressured IASB Chairman Considered Resigning, 2008). Contudo, o que foi ignorado é que o IASB estipulou uma exigência de divulgação que obrigou os bancos que reclassificaram a revelar o valor de seus lucros sem a reclassificação. A Comissão Europeia aprovou a norma apenas dois dias depois, estabelecendo um recorde de atuação veloz. O Deutsche Bank foi um dos primeiros a aproveitar esse presente contábil e foi obrigado a divulgar que seu lucro antes de impostos de $€ 93$ milhões no terceiro trimestre teria sido uma perda antes de impostos de $€ 732$ milhões sem a reclassificação (ver Stice \& Stice, 2010).

A precipitada rendição do IASB à exigência da Comissão Europeia proporcionou tempo pensar àqueles nos EUA, talvez até dentro da SEC, acerca da credibilidade do conselho como normalizador capaz de defender seus princípios. Os críticos norte-americanos utilizaram esse episódio como prova de que não se pode confiar no IASB diante de pressões políticas, em especial de dentro da Europa (ver, por exemplo, Deans \& Mott, 2008; Selling, 2008; Ciesielski 2009). Porém, esses críticos esqueceram que o próprio FASB foi dominado pela SEC em 1978 em relação ao tratamento contábil de empresas produtoras de petróleo e gás (SFAS 19) e capitulou perante as forças políticas sobre a contabilização da reestruturação de dívidas problemáticas em 1977 (SFAS 15), contabilização de investimentos em débitos e ações de capital em 1993 (SFAS 115), contabilização de compensação baseada em ações em 1995 (SFAS 123), aspectos de divulgação sobre resultados acumulados em 1997 (SFAS 130) e contabilização de patrimônio de marca e outros ativos intangíveis em 2001 (SFAS 142) (Zeff, 2010).

Durante a crise econômica e financeira, uma das questões que importunaram o IASB e, também, o FASB, foi o conflito entre seu objetivo declarado de prestar informações transparentes aos investidores no mercado de capitais -a serviço dos reguladores do mercado de valores mobiliários - e o forte desejo dos bancos e reguladores das atividades bancárias de que (1) as normas do IASB projetem uma imagem de estabilidade financeira e (2) não resultem em "crises do crédito" ao deprimir o capital bancário em momentos de preços de títulos em queda. Durante momentos econômicos ruins, os interesses declarados dos reguladores do mercado de valores imobiliários e dos reguladores bancários podem muito bem colidir e o normalizador pode ser submetido a intensa pressão política para acomodar os últimos. A pressão específica sobre o IASB para acomodar as preocupações dos bancos em outubro de 2008 não teria acontecido em momentos econômicos bons. O FASB foi submetido a pressões semelhantes durante uma audiência do U.S. House Subcommittee em março de 2009, encorajada por uma campanha agressiva de lobbying pela American Bankers Association (ver Pulliam \& McGinty, 2009). Preocupações têm sido manifestadas no G20, em reuniões dos ministros de economia e finanças da UE e por reguladores bancários sobre o papel que preveem para as normas contábeis na preservação da estabilidade financeira ${ }^{32}$.

\subsection{Outras Alterações Constitucionais}

No início de 2009, os diretores da Fundação IASC, hoje conhecida como a Fundação IFRS, efetuaram duas alterações importantes na constituição. Decidiu-se que um normalizador global deveria ser visto apoiando-se explicitamente na vila global. Revisou a constituição para aumentar a quantidade de membros do conselho de 14 para 16 e especificou cotas geográficas de associação: 4 da América do Norte, 4 da Europa, 4 da Ásia/Oceania, 1 da América do Sul, 1 da África, e 2 para alcançar equilíbrio geográfico. Além disso, os membros em tempo parcial não mais seriam 2, mas 3 dos 16 membros poderiam trabalhar em tempo parcial.

Além disso, em resposta às críticas levantadas no Parlamento Europeu e em outras instâncias, os diretores concordaram que um normalizador do setor privado afirmando sua atuação em prol dos interesses públicos deveria ser supervisionado por lideranças do mundo regulatório. Portanto, os diretores revisaram a constituição para conceder certa autoridade a um conselho de monitoramento, que aprovaria a indicação de diretores e supervisionaria seu desempenho geral. $\mathrm{O}$ conselho de monitoramento, pelo menos inicialmente, incluiu representantes da SEC, da Financial Services Agency japonesa, da Comissão Europeia, e dos Emerging Markets and Technical Committees do IOSCO. O Comitê de Basileia de Supervisão Bancária participa na condição de observador. A presidente da SEC, Mary Shapiro, tem participado regularmente das reuniões do conselho de monitoramento, que serviram para incrementar sua compreensão das operações e dos objetivos do IASB e permitiram que conhecesse outros reguladores do mundo também interessados no trabalho do conselho. Sua experiência no conselho de monitoramento pode fundamentar a decisão que acabará apoiando se, e quando, as empresas norte-americanas negociadas em bolsa podem, ou devem, utilizar as IFRS em suas demonstrações financeiras.

\subsection{O IASB e o FASB Pressionam para Completar sua Convergência de Projetos Principais até 2011}

Prosseguindo em sua série de MdEs, ambos os conselhos têm-se esforçado para completar vários grandes projetos de convergência: instrumentos financeiros, contratos de seguro, arrendamento e reconhecimento de receitas. Os conselhos esperavam completar esses projetos até junho de 2011, quando os últimos três membros originais do IASB, inclusive o Presidente Tweedie, estariam aposentados, mas a complexidade das questões, aliada aos diferentes estilos de trabalho e constituição dos dois conselhos, obrigaram a um adiamento de suas datas de término. A aposentadoria repentina do Robert Herz como presidente do FASB em agosto de 2010 e a redução do tamanho do conselho pelos diretores da FAF, supervisora do FASB de 7 para 5 a partir de $1^{\circ}$ de julho de 2008 e depois, abruptamente, anunciou um novo aumento para 7 em agosto de 2010, não contribuíram para deliberações suaves e fáceis entre ambos os conselhos. 
Os conselhos também estavam sendo pressionados pelo G20, que afirmou em comunicado após sua reunião de cúpula em Pittsburgh, EUA, em setembro de 2009: "Estamos conclamando nossos órgãos contábeis internacionais para redobrar seus esforços para [...] completar seu projeto de convergência até junho de 2011" (Tweedie, 2010). Após sua reunião de cúpula em Toronto, em junho de 2010, o G20 "incitou" ambos os conselhos a completar seus projetos de convergência até o final de $2011^{33}$.

\subsection{IFRS para PMEs}

Em julho de 2009, o conselho lançou um tipo diferente de pronunciamento: uma norma de 230 páginas, independente, sobre as IFRS para Pequenas e Médias Empresas (PMEs). Paul A. Pacter, atual membro do conselho, foi o membro da equipe que dirigiu o desenvolvimento da norma. Seu objetivo é simplificar as normas do IASB para uso por PMEs, que, em muitos países, são obrigadas a registrar suas demonstrações financeiras auditadas com uma entidade pública de registro. Alguns membros do conselho não eram a favor da emissão de uma norma exclusiva para PMEs, e um membro discordou da norma por esse motivo. Apesar disso, a norma tem atraído grande interesse. Em julho de 2011, somente dois anos após a emissão da norma, o IASB anunciou que 74 jurisdições a adotaram ou anunciaram planos de fazê-lo ${ }^{34}$.

\subsection{Progresso das Decisões Nacionais para Adotar ou Convergir com as IFRS}

Além das decisões da UE e da Austrália para exigir a adoção das IFRS até 2005 para as empresas negociadas em bolsa, adoções jurisdicionais ou plena convergência para as empresas negociadas em bolsa entraram em vigor na África do Sul, Nova Zelândia, Israel, Hong Kong, Brasil, Chile, Canadá e Coreia, além de muitas economias emergentes e países em desenvolvimento (mas, talvez, com desvios). A Financial Services Agency (FSA) japonesa decidiu, em 2009, permitir que as empresas negociadas em bolsa com operações internacionais começassem a utilizar as IFRS a partir do ano fiscal findo em 2010, e a FSA pretende decidir logo sobre o possível uso compulsório das IFRS por todas as empresas negociadas em bolsa (Yorihiro, 2011). A China já fez a maior parte do caminho em direção à plena convergência com as IFRS e declara que os resultados da divulgação contábil das empresas chinesas negociadas em bolsa não são tão diferentes do que seria alcançado com a plena convergência (Hoogervorst, 2011). A Îndia iniciou um processo de convergência, mas o lobbying persistente até agora causou alguns desvios significativos da plena adoção das IFRS ${ }^{35}$. Desde 2005, o SIX Swiss Exchange permitiu que as empresas em seu conselho principal utilizassem os US GAAP ou IFRS, enquanto os GAAP suíços podem ser utilizados apenas pelas empresas no conselho secundário (Achleitner \&
Eberle, 2010, p. 232). Mais de $90 \%$ das empresas no conselho principal utilizam as IFRS.

O papel do Banco Mundial ao convencer as economias emergentes e os países em desenvolvimento a convergir ou adotar as IFRS não pode ser subestimado. Ao longo dos últimos 12 anos, aproximadamente, o Banco desenvolveu mais de 80 estudos de países conhecidos como Reports on the Observance of Standards and Codes (ROSC), Accounting and Auditing que, entre outros aspectos, desenvolvem uma revisão aprofundada das normas e práticas contábeis em cada país e, em uma seção sobre as recomendações políticas, incita o país a adotar as IFRS nas entidades de interesse público ou, se já o fez ou iniciou sua convergência com as IFRAS, a fortalecer sua aplicação das IFRS (World Bank reports on the observance of standards and codes (ROSC): overview of the ROSC Accounting and Auditing Program, 2004) ${ }^{36}$.

\subsection{Outros Grupos de Interesse Geográficos se Organizam para Competir com a Europa e os EUA}

No início do IASB, a Europa e os EUA eram as regiões cuja influência o IASB mais sentia - a Europa devido à proximidade e seu compromisso inicial de proporcionar um grande núcleo de empresas adotantes e os EUA por causa (1) do respeito concedido à SEC e ao FASB e (2) do profundo desejo das lideranças do IASB de alcançar a aceitação norte-americana de suas normas. Recentemente, outras regiões têm-se organizado para competir com a Europa e os EUA pela atenção do IASB. Em 2009, os normalizadores ou órgãos contábeis de 16 países fundaram o Asian-Oceanian Standard-Setters Group (AOSSG), cujo número de membros aumentou, desde então, para 25. Tem-se tornado proativo e, recentemente, lançou uma declaração de visão (A Driving Wind for IFRS from Asia-Oceania, 2011). Em 2011, os normalizadores ou órgãos contábeis de cinco países sul-americanos e do México fundaram o Grupo de Normalizadores Sul-Americanos (GLASS), organizado principalmente pelo Brasil (CReCER, 2011). Em 2005, um órgão conhecido como National Standard-Setters (NSS) foi constituído e presidido por Ian Mackintosh, então presidente do UK Accounting Standards Board, que se tornou vice-presidente do IASB em julho de 2011. O NSS é, atualmente, presidido por Patricia O'Malley, antigo membro do conselho do IASB pelo Canadá, e tem realizado reuniões semestrais e enviado suas perspectivas ao IASB sobre uma ampla série de questões. Mais de duas dúzias de normalizadores, além de observadores que abrangem o IASB, EFRAG e a SEC, participam de suas reuniões regularmente.

Como visto, não faltam ao IASB grupos para aconselhá-lo sobre seu programa de trabalho e suas prioridades, além das cartas de comentário que costuma receber sobre os documentos de reflexão e projetos de normas. 


\section{ALGUNS DESAFIOS A SER ENFRENTADOS PELO IASB}

Alguns dos desafios que o IASB enfrenta, como normalizador contábil global, estão fora de seu controle. Contudo, apesar disso, o IASB tem influência. Abaixo são discutidos cinco desafios.

Primeiro, como o IASB deve lidar com a eventual decisão da SEC de adotar, convergir ou continuar estudando as IFRS como arcabouço de divulgação contábil a ser utilizado pelos emissores norte-americanos? O processo de convergência mútua entre as IFRS e US GAAP, que tem sido uma política declarada do IASB e do FASB desde 2002, com certeza, não ultrapassará as datas finais dos grandes projetos que estão sendo completados ${ }^{37}$. Os países que adotaram as IFRS, além da liderança do IASB, acreditam que tenha chegado a hora da SEC, enfim, decidir quanto a se comprometer, ou não, com as IFRS. Caso não, o IASB deve considerar as consequências de um mundo IFRS sem os EUA. Diversos países, inclusive Japão e China, estão observando o próximo movimento da SEC como sinal que poderia influenciar a direção e o escopo de seu próprio compromisso $^{38}$. Apesar dos EUA corresponderem a apenas $31 \%$ da capitalização do mercado global de valores mobiliários no final de 2009, uma queda significativa dos 52\% em 2001 (Tweedie, 2011), o mercado de capitais norte-americano continua sendo o maior e mais importante no mundo, e a SEC é o regulador do mercado de valores mobiliários mais respeitado no mundo.

Segundo, o IASB terá de administrar e equilibrar o feedback diverso dos grupos regionais recém-constituídos de normalizadores na Ásia-Oceania e América Latina, além do aconselhamento que já recebe da Europa e dos EUA e dos National Standard Setters. Como os países e regiões começaram a apreciar o pleno impacto das decisões do IASB na divulgação contábil de suas empresas e, também, nas consequências econômicas e políticas percebidas como resultado dessas decisões, o aconselhamento recebido de diferentes partes do mundo tornou-se mais organizado e, talvez, mais insistente.

Terceiro, o IASB necessita estimular melhorias no desempenho dos reguladores do mercado de ações no alcance do cumprimento, por parte das empresas negociadas em bolsa, das IFRS. Há grande variação na eficácia do desempenho regulatório, inclusive dentro da UE, e ainda mais entre os países no resto do mundo, particularmente em economias emergentes e países em desenvolvimento. A um compromisso de um país cujas empresas negociadas em bolsa são obrigadas a utilizar as IFRS falta credibilidade se não for apoiado por um regulador vigilante e proativo, seja no setor público ou privado. Na UE, o antigo Committee of European Securities Regulators publicou autoavaliações e revisões por pares do desempenho dos reguladores em seus 27 Estados membros, além da Noruega e Islândia (ver, por exemplo, Final report of the review panel concerning the updated self assessment and peer review of CESR's Standard no. 1 on Financial Information, 2009), mas tinha pouca influência para aprimorar seu desempenho. Seu sucessor, a partir de janeiro de 2011, a European Securities and Markets Authority, tem um tanto a mais de poder nessas questões. Em outros lugares no mundo, o IOSCO apenas consegue convencer os reguladores nacionais a se tornar mais proativos quando encontram práticas deficientes de divulgação contábil, mas não tem autoridade além da persuasão.

Quarto, naquelas jurisdições onde as IFRS são o conjunto mandatório de normas para as empresas negociadas em bolsa, a confirmação do cumprimento com as IFRS pela empresa ou pelo auditor, ou ambos, pode referir-se ao arcabouço de divulgação contábil de tal forma que não esteja claro ao público se, e em qual grau, corresponde às IFRS como emitidas pelo IASB. Por exemplo, na UE, exige-se que as empresas e auditores confirmem o cumprimento com as "IFRS conforme adotadas pela UE". Como os leitores em outras partes do mundo podem saber se "conforme adotadas pela UE" é igual a "conforme emitidas pelo IASB"? Em Hong Kong, onde o pleno uso das IFRS é obrigatório, é improvável que se exija que as empresas negociadas em bolsa e seus auditores confirmam seu cumprimento com as Hong Kong Financial Reporting Standards ao invés das IFRS. A Índia, ao completar sua transição para as IFRS, exigirá que as empresas e auditores confirmem seu cumprimento com as normas contábeis indianas e com as IFRS. Em fevereiro de 2008, o Comitê Técnico do IOSCO recomendou que as empresas em países que utilizam as IFRS fossem responsáveis por informar se suas demonstrações contábeis cumprem com as "IFRS conforme emitidas pelo IASB" (IOSCO Technical Committee, 2008). Os auditores devem carregar a mesma responsabilidade. $\mathrm{O}$ IASB pode contribuir ao estimular essas e outras jurisdições a permitir que os leitores das demonstrações contábeis de suas empresas negociadas em bolsa sejam informados sobre se, e em qual grau, seu arcabouço de divulgação contábil corresponde plenamente às IFRS.

Quinto, e esse desafio está longe do controle do IASB, deve ser tomado o devido conhecimento no desenvolvimento das normas e interpretações sobre as diferenças na maneira fundamental de fazer negócios em diferentes países. Por exemplo, como uma norma sobre demonstrações contábeis consolidadas pode ser elaborada para refletir as relações substantivas no keiretsu japonês e chaebol coreano, as redes de empresas afiliadas que podem não ter uma empresa controladora? $\mathrm{Na}$ China, a maior parte dos negócios é feita por entidades públicas, não por empresas do setor privado. Em qual grau as normas contábeis devem fazer provisões explícitas para as diferentes formas de fazer negócios nos países islâmicos? A insistência no uso de um único método contábil em uma norma em todos os países pode, em alguns momentos, meramente salientar essas diferenças, sem promover a verdadeira comparabilidade glo- 
bal. Alcançar a comparabilidade global não é sinônimo de alcançar a comparabilidade em um único contexto nacional, onde há estímulos fiscais e hábitos comerciais em comum (Zeff, 2007b). O IASB deve tomar suas decisões com sabedoria e à luz do que parece ser exigido para promover a verdadeira comparabilidade global, o que pode significar a provisão de abordagens opcionais em sintonia com as circunstâncias nacionais expressamente especificadas.

\section{CONCLUSÃO}

A maioria das pessoas que acompanha o trabalho do IASB atualmente pode não saber quase nada sobre seu fundamental antecessor, o IASC. Entretanto, sem o pioneirismo do IASC, o IASB não existiria hoje. Em 1973, o IASC foi lançado em tempo parcial como o primeiro normalizador internacional, descendente dos órgãos contábeis profissionais em nove países. Para persuadir um mundo descrente, ele teve de construir um histórico de amplas consultas processuais e uma produção de normas competentes, inclusive uma atenção à necessidade de aumentar a qualidade de suas normas iniciais genéricas. Ao final, conquistou os normalizadores nacionais, reguladores dos mercados de ações, o Banco Mundial e, final e fundamentalmente, a Comissão Europeia. Após a reestruturação necessária do IASC, ressurgiu como o IASB em 2001, com uma clientela prometida de aproximadamente 7.000 empresas negociadas em bolsa na União Europeia. Trabalhava, então, praticamente em tempo integral com uma equipe técnica muito maior e supervisionada por um conselho de diretores eminentes, que levantaram o apoio financeiro exigido. Suas normas não eram mais consideradas suplementos voluntários às normas nacionais, mas sua intenção era substituir as normas nacionais ao redor do mundo. Em menos de dez anos, o IASB alcançou muito. Independentemente do que poderia se dizer sobre pequenas rachas na armadura da comparabilidade global, por causa das isenções ou exceções concedidas por determinados países ou pelos atrasos tolerados na aceitação do conjunto completo das normas do IASB - e alguns países convergiram com as IFRS somente até certo ponto - a comparabilidade dos relatórios financeiros empresariais ao redor do mundo, hoje, é muito superior ao nível anterior a 2005, quando a União Europeia indicou o caminho com sua exigência de adoção das IFRS em seus 25 Estados membros. Como sugerido, ainda há muito a ser feito. O IASB deve proporcionar normas fundamentais sobre temas que atormentaram até os normalizadores nacionais mais avançados. E deve continuar a redefinir e melhorar e ampliar o leque de suas normas, especialmente com o surgimento de novas questões e problemas. A lista dos grandes países que adotaram ou convergiram com as IFRS já é impressionante. E, com o tempo, aqueles recalcitrantes se acostumarão à ideia de que os relatórios financeiros, diferente da lei, devem ser os mesmos ao redor do mundo, já que os mercados de ações, hoje, são uma coisa só.

\section{Referências}

Achleitner, A.-K., \& Eberle, R. (2010). Switzerland. In G. J. Previts, P. Walton, \& P. Wolnizer (Ed.), A global history of accounting, financial reporting and public policy: Europe (chap. 9). Bingley: Emerald.

Adoption of International Accounting Standards by 2005. (2002): Bulletin of the Financial Reporting Council, 4(3). Retrieved from http://www. iasplus.com/resource/ausfrc.pdf

A driving wind for IFRS from Asia-Oceania. (2011). A vision paper of the Asian-Oceanian Standard-Setters Group (AOSSG). Retrieved from http://www.aossg.org/docs/About_Us/Vision_Paper.pdf

AICPA Council. (2008): AICPA Council votes to recognize the International Accounting Standards Board as a designated standard setter. AICPA News Release (May 18). Retrieved from http://www.ifrs. com/ updates/aicpa/Press_Release_May18.html

American Institute of Certified Public Accountants. (1964). Professional accounting in 25 countries. New York: AICPA.

American Institute of Certified Public Accountants. (1972). Establishing financial accounting standards. New York: AICPA.

Berger, A. (2010). The development and status of enforcement in the European Union. Accounting in Europe, 7(1), 15-35.

Beswick, P. A. (2010). Remarks before the 2010 AICPA National Conference on Current SEC and PCAOB developments (Dec. 6). Retrieved from http://www.sec.gov/news/speech/2010/ spch120610pab.htm

Camfferman, K., \& Zeff S. A. (2007). Financial reporting and global capital markets: a history of the International Accounting Standards Committee, 1973-2000. Oxford: Oxford University Press.

Casey, W. J. (1972). Toward common accounting standards. Speech to the Conference on Financial Reporting, Commission des Operations de Bourse, Paris, May 19. Retrieved from http://www.sec.gov/ news/ speech/1972/051972casey.pdf

Ciesielski, J. (2009). Why a road map now? (available from the author, Dec. 3).

CReCER. (2011). Notable events and highlights (Aug. 6). Retrieved from
http://web.ifac.org/downloadAFAC-News-August-2011.pdf

Cummings, J. P. (1976). International Accounting Standards: The Outlook.

In The 4th Ross Institute Seminar on Accounting. New York: New York

University, May, 2-8.

Deans, S., \& Mott, D. (2008). EU accounting decision: credibility of European accounting at stake (available from the author, Oct. 15).

Enevoldsen, S., \& Oversberg, T. (2008). Importance of a European voice in international standard setting: the role of EFRAG. In H:-G. Bruns, R. H. Herz, H.-J. Neubiirger, \& D. Tweedie (Ed.), Globale Finanzberichterstattung/Global Financial Reporting (pp. 89-106). Stuttgart: Schaffer-Poeschel Verlag.

Ernst \& Young. (2006). Observations on the implementation of IFRS. London: EYGM.

EU Financial Reporting Strategy: the way forward. (2000). Communication from the Commission to the Council and the European Parliament (June 13). Retrieved from http://eur-lex.europa. eu/LexUriServ/\%20LexUriServ.do?uri=COM:2000:0359:FIN:EN:PDF

Final report of the review panel concerning the updated self assessment and peer review of CESR's Standard no. 1 on Financial Information (Sep. 25). (2009). Retrieved from http://www.esma.europa.eu/system/ files/09_374.pdf

Garrett Jr., R. (1973). The internationalization of our securities markets. Speech to the Boston Stock Exchange (Sep. 25). Retrieved from http:// www.sec.gov/news/speech/1973/092573garrett.pdf

Hoogervorst, H. (2011). China and IFRS: an opportunity for leadership in global financial reporting (speech in Beijing, July 29). Retrieved from http://www.ifrs.org/News/Announcements+and+Speeches/ Hans+Hoogervorst+Beijing-fspeech+July+2011.htm

Hopwood, A. G. (1994). Some reflections on "The harmonization of accounting within the EU". The European Accounting Review, 3(2), 241-253.

IAS Regulation 1606/2002 (19 July). (2002). Retrieved from http://www. esma.europa.eu/system/files/Reg_1606_02.pdf 
International Organization of Securities Commissions. (1988). Annual Report 1988. Montreal: IOSCO.

IOSCO Technical Committee. (2000). IASC Standards: assessment report (May). Retrieved from http:// www.iosco.org/library/pubdocs/pdf/ IOSCOPD109.pdf

IOSCO Technical Committee. (2008). Statement on providing investors with appropriate and complete information on accounting frameworks used to prepare financial statements (Feb. 6). Retrieved from http://www.iosco.org/library/pubdocs/pdf/IOSCOPD262.pdf

Kirsch, R. J. (2006). The International Accounting Standards Committee: a political history. The Netherlands: Wolters-Kluwer.

Meltdown at the IASB? (2008). World Accounting Report, 11(9), 2-3.

Multinational Companies (special report). (1963). Business Week (Apr. 20), 62-86.

New Chairman Appointed. (2009). World Accounting Report, 12(1), 7

Nicolaisen, D. T. (2005). A securities regulator looks at convergence. Northwestern Journal of International Law \& Business, 25(3), 631-686. Retrieved from http://www.sec.gov/news/speech/spch040605dtn.htm

Nobes, C. W. (1983). A judgemental international classification of financial reporting practices. Journal of Business Finance \& Accounting, 10(1), 1-19.

Nobes, C. W. (2011). IFRS practices and the persistence of accounting system classification. Abacus, 47(3), 267-283.

Nobes, C. W., \& Zeff, S. A. (2008). Auditors' affirmations of compliance with IFRS around the world: an exploratory study. Accounting Perspectives, 7(4), 279-292.

Pacter, P. (2005). What exactly is convergence? International Journal of Accounting, Auditing and Performance Evaluation, 2(1/2), 67-83. Retrieved from: http://www.iasplus.com/resource/2005ijaape.pdf

Pressured IASB Chairman Considered Resigning (Nov. 13). (2008). Retrieved from http://www.accountingtoday.com/news/29825-1.html

Pulliam, S., \& McGinty, T. (2009). Congress helped banks defang key rule. Wall Street Journal, (June 3), A1, A14. Retrieved from http:// people.tamu.edu/ jstrawser/acct $229 \mathrm{~h} /$ Current $\% 20$ Readings/ $12 . \% 20$ Congress\%20Helped\%20Banks\%20Defang\%20Key\%20Rule\%20-\%20 WSJ.com\%20(Investments).pdf

Recommendations on Shaping IASC for the Future. (1999). London: IASC

Reference to the financial reporting framework in the EU in accounting policies and in the audit report and applicability of endorsed standards (communication to FEE member bodies). (2005): Brussels: Fédération des Experts Comptables Européens.

Roberts, C. B. (2010). Segment reporting. In C. Nobes \& R. Parker, Comparative international accounting (11th ed., chap. 19). Harlow: Pearson.

Scheid, J.-C., \& Walton, P. (1992). European financial reporting: France. London: Routledge.

Securities and Exchange Commission. (1973). Statement of policy on the establishment and improvement of accounting principles and standards (Accounting Series Release n. 150, Dec. 20). Washington, DC: U.S. Government Printing Office.

Securities and Exchange Commission. (2000). International Accounting
Standards (concept release, February). Retrieved from http://www.sec. gov/rules/concept/34-42430.htm

Selling, T. (2008). Amended IAS 39: exploding the myth of an independent IASB (Nov. 3). Retrieved from http://accountingonion.typepad.com/ theaccountingonion/2008/11/index.html

Skinner, R. M. (1972). Accounting principles: a Canadian viewpoint. Toronto: Canadian Institute of Chartered Accountants.

Stice, E. K., \& Stice J. D. (2010). Count U.S. out? How the French put U.S. adoption of International Accounting Standards on the rocks. Marriott Alumni Magazine, (Fall), 12-15.

Tweedie, S. D. (2010). Chairman of the IASB addresses ECOFIN Meeting (Mar. 16). Retrieved from http://www.ifrs.org/News/ Announcements+and+Speeches/ChairmanAddressesECOFIN.htm

Tweedie, S. D. (2011). Sir David Tweedie Addresses the US Chamber of Commerce (Mar. 10). Retrieved from http://wwwiffrs.org/News/. Announcements+and+Speeches/convergence+or+not-fspeech.htm

Van Hulle, K. (2008). IFRS as accounting standards for Europe. In H.-G. Bruns, R. H. Herz, H.-J. Neubiirger, \& D. Tweedie (Ed.), Globale Finanzberichterstattung/Global Financial Reporting (pp. 71-87). Stuttgart: Schaffer-Poeschel Verlag.

Veron, N. (2007). The Global Accounting Experiment. Brussels: Bruegel.

Walton, P. (2009). An executive's guide for moving from U.S. GAAP to IFRS. New York: Business Expert Press.

Work plan for the consideration of incorporating international financial reporting standards into the financial reporting system For U.S. issuers: exploring a possible method of incorporation (Securities and Exchange Commission staff paper, May 26). (2011). Retrieved from http://www.sec.gov/ spotlight/globalaccountingstandards/ifrs-workplan-paper-052611.pdf

World Bank reports on the observance of standards and codes (ROSC) overview of the ROSC Accounting and Auditing Program. (2004). Washington, DC: The World Bank Group. Retrieved from http://www. worldbank.org/ifa/rosc_aa_overview.pdf

Yorihiro, K. (2011). Update: IFRS developments in Japan. Financial Executive, 27(8), 14-15.

Zeff, S. A. (1979). Forging accounting principles in New Zealand. Wellington: Victoria University Press.

Zeff; S. A. (1997). The U.S. Senate votes on accounting for employee stock options. In S. A. Zeff \& B. G. Dharan, Readings and notes in financial accounting (pp. 507-517). New York: McGráw-Hill.

Zeff, S: A. (2002). "Political" lobbying on proposed standards: a challenge to the IASB. Accounting Horizons, 16(1), 43-54.

Zeff, S. A. (2007a). The SEC rules historical cost accounting: 1934 to the 1970s. Accounting and Business Research, 37(special issue), 49-62.

Zèff, S. A. (2007b). Some obstacles to global financial reporting comparability and convergence at a high level of quality. The British Accounting Review, 39(4), 290-302.

Zeff, S, A. (2010). Political lobbying on accounting standards: US, UK, and international experience. In C. Nobes'\& R. Parker, Comparative international accounting (11th ed.; chap. 11). Harlow: Pearson. 